\title{
AR Signaling in Breast Cancer
}

\author{
Bilal Rahim and Ruth O'Regan *
}

Department of Medicine, Division of Hematology \& Oncology, University of Wisconsin School of Medicine and Public Health, Madison, WI 53792, USA; brahim@uwhealth.org

* Correspondence: roregan@medicine.wisc.edu; Tel.: +1-608-262-9368

Academic Editor: Emmanuel S. Antonarakis

Received: 5 December 2016; Accepted: 18 February 2017; Published: 24 February 2017

\begin{abstract}
Androgen receptor (AR, a member of the steroid hormone receptor family) status has become increasingly important as both a prognostic marker and potential therapeutic target in breast cancer. AR is expressed in up to $90 \%$ of estrogen receptor (ER) positive breast cancer, and to a lesser degree, human epidermal growth factor 2 (HER2) amplified tumors. In the former, AR signaling has been correlated with a better prognosis given its inhibitory activity in estrogen dependent disease, though conversely has also been shown to increase resistance to anti-estrogen therapies such as tamoxifen. AR blockade can mitigate this resistance, and thus serves as a potential target in ER-positive breast cancer. In HER2 amplified breast cancer, studies are somewhat conflicting, though most show either no effect or are associated with poorer survival. Much of the available data on AR signaling is in triple-negative breast cancer (TNBC), which is an aggressive disease with inferior outcomes comparative to other breast cancer subtypes. At present, there are no approved targeted therapies in TNBC, making study of the AR signaling pathway compelling. Gene expression profiling studies have also identified a luminal androgen receptor (LAR) subtype that is dependent on AR signaling in TNBC. Regardless, there seems to be an association between AR expression and improved outcomes in TNBC. Despite lower pathologic complete response (pCR) rates with neoadjuvant therapy, patients with AR-expressing TNBC have been shown to have a better prognosis than those that are AR-negative. Clinical studies targeting AR have shown somewhat promising results. In this paper we review the literature on the biology of AR in breast cancer and its prognostic and predictive roles. We also present our thoughts on therapeutic strategies.
\end{abstract}

Keywords: AR signaling; AR/PARP interplay; AR/BET interplay; breast cancer

\section{Introduction}

Androgen receptor (AR) signaling has become increasingly important in understanding the biology of breast cancer, and serves as a potential therapeutic target in the era of precision medicine. Previously, breast cancer has been categorized based on hormone receptor (HR) status, and the presence or absence of human epidermal growth factor 2 (HER2) amplification. More recently, it has become apparent that the AR pathway is associated with breast tumor carcinogenesis, with differing mechanisms dependent on co-expression of HR or HER2 amplification [1,2] Although our understanding is still early, this signaling pathway has important prognostic and therapeutic implications. This review will aim to further clarify the complexities of the AR pathway in relation to breast cancer tumorigenesis, prognostic associations in relation to HR expression and HER2 amplification and potential therapeutic options.

\section{AR Pathway in Breast Cancer}

The AR is a steroid-hormone activated transcription factor belonging to the nuclear receptor superfamily, a group that also includes the estrogen receptor (ER) and progesterone receptor (PR). 
Upon binding of its androgen ligand, the protein translocates to the nucleus where it stimulates transcription of androgen-responsive genes [2,3]. More recently, non-genomic actions of the AR signaling pathway have been described and are still being investigated in both normal female tissue and in tumor carcinogenesis [4]. AR binds androgens that are produced in a normal physiological manner from the female adrenal glands and ovaries, and in descending order of concentration include dehydroepiandrosterone sulphate (DHEAS), dehydroepiandsoterone (DHEA), androstenedione (A), testosterone (T), and dihydrotestosterone (DHT) (Figure 1) [5,6]. Only testosterone and DHT bind directly to AR, and are primarily formed by peripheral conversion of DHEAS, DHEA, and A in adipose tissue, liver and skin [5,7]. It is important to note that although testosterone can itself bind to AR, or be converted to the more potent DHT via $5 \alpha$ reductase, it can also be converted to estradiol (E2) via the aromatase enzyme that is found in numerous tissues including the breast [8-10]. This conversion to estradiol is important, as estradiol serves as the primary ER ligand for both ER $\alpha$ and ER $\beta$ receptors in breast cancer. ER $\alpha$ has been shown to have proliferative effect on tumors, while ER $\beta$ has been associated with anti-proliferative effect, though these mechanisms are complex and our understanding remains limited [11-14].

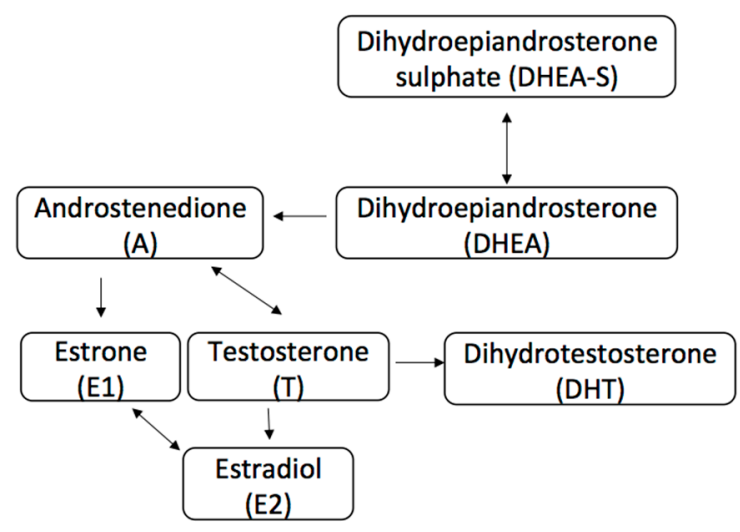

Figure 1. Abbreviated androgen and estrogen pathway. Arrows represent direction of enzymatic conversion.

AR is found in up to $70 \%-90 \%$ of all breast cancers, making it more abundant than ER or PR activity [15-19]. However, identifying exact percentages of AR expression among the various breast cancers-HR-positive, HER2-positive, or triple negative breast cancer (TNBC)—is somewhat challenging due to considerable variability in methodology, including differing locations of expression (cytoplasmic versus nuclear), cut off points for immunohistochemical (IHC) receptor expression $(\geq 1 \%$, $\geq 5 \%$ or $\geq 10 \%$ ), and the antibody used in staining. One very large systematic review aimed to address AR expression in ER-positive versus ER-negative breast cancers by analyzing 19 studies, including 7693 patients, and found AR co-expression with ER-positive disease to be $74.8 \%$ [20]. AR was also found in ER-negative tumors at a lower rate of $31.8 \%$ from the same study, although other studies show significant variability in this percentage depending on HER2 or TNBC status [20]. For example, HR-negative and HER2-positive breast cancers seem to express AR in the range of $50 \%-60 \%$; TNBC is generally between $20 \%$ and $40 \%[15,16,21-28]$. AR is also variably expressed in certain histologically distinct subsets of mammary epithelial cells, including invasive apocrine carcinomas, with molecular apocrine cells uniformly expressing AR but not ER or PR [29,30]. Luminal epithelial cells have also been found to express AR in up to 30\%, often with co-expression of ER and PR [31].

Gene expression profiling has also led to distinct molecular subtyping that is sometimes used to classify breast cancer, and these tumors seem to show variable rates of AR expression [32,33]. For example, the luminal A and luminal B subtypes, as defined by ER positivity seem to express AR anywhere from $50 \%$ to $90 \%$ depending on the study. The HER2-positive molecular subtype expresses AR between approximately $20 \%-60 \%$, and TNBC molecular subtype between $20 \%$ and $50 \%[34,35]$. 
In regards to AR activity in breast cancer carcinogenesis, multiple in vitro studies using several laboratory breast cancer cell lines (i.e., MCF-7, T47-D, and BT20) have shown an anti-proliferative effect of AR antagonism [1,36-39]. Interestingly, in the presence of ER $\alpha$, the AR pathway can be either antagonistic or agonistic to tumorigenesis, and at least partially is influenced by the level of receptor expression and availability of their respective ligands [40-43]. Alternatively, ER $\alpha$-negative and AR-positive breast cancers fall into a category termed the "molecular apocrine" subtype, with typically distinct histological features of eosinophilic and granular cytoplasm [44]. Within this subtype, a preclinical study by Doane and colleagues utilizing the cell line MDA-MB-453 found the absence of ER but continued dependence on hormonally regulated transcription, which was previously thought to be solely the product of ER activation. Further gene expression profiling revealed the presence of $\mathrm{AR}$, and incubation of the cell line with synthetic androgen led to proliferation that could be blocked by the anti-androgen flutamide [45]. The proliferative activity of AR seems to be consistent in the presence of HER2, with at least partial "cross-talk" between the receptor pathways, and in TNBC as well [46-48]. This heterogeneity of AR signaling in relation to co-expression of ER $\alpha$, HER2 and in TNBC will be discussed in further detail in their respective sections of this paper.

\section{AR Pathway in ER+ Breast Cancer}

Like AR, ER is a steroid hormone receptor. There are naturally two receptors expressed in normal breast tissue, ER $\alpha$ and ER $\beta$, which are involved in the development of reproductive organs, bone density, cell cycle regulation, DNA replication and variety of other processes that occur through both genomic and non-genomic mechanisms. Its ligand is estradiol, and in normal breast tissue ER $\beta$ is the dominant receptor. In breast cancer, ER $\alpha$ expression increases and is implicated in tumorigenesis [49]. The function of AR depends largely on the level of co-expression of ER $\alpha$ in HR-positive breast cancer (i.e., luminal breast cancer). Interestingly, many pre-clinical studies show differing proliferative versus anti-proliferative effects in ER $\alpha$ and AR-positive breast cancer that correlates with variation in the ratio of these steroid receptors and the availability of their respective ligands (i.e., estradiol and DHT). As noted earlier in this paper, androgens can be peripherally converted to estradiol (Figure 1), making the interplay between androgens and estrogens in patients expressing both AR and ER quite complex. Early in vitro studies have tried to elucidate the complex relationship between AR and ER expression and the variable responses to hormones and their antagonists in breast cancer cells.

Some studies show AR agonists to actually have anti-tumor effect in the setting of ER $\alpha$. This has been demonstrated through in vitro modeling in which higher levels of AR confer anti-proliferative effects in the MCF-7 cell line [41]. Some older in vitro studies show increased apoptotic activity with the use of androgens, as well as down regulation of the $b c l-2$ proto-oncogene, which could be reversed with the addition of the anti-androgen hydroxyflutamide [50,51]. There are even some older clinical trials that have demonstrated that treatments with exogenous androgens can successfully treat certain breast cancers, with regression rates of approximately $20 \%$ [42]. These early clinical studies, though, did not categorize the receptor status of treated patients.

Overexpression of AR in the MCF-7 breast cancer cell line, as postulated by Britton and colleagues, is thought to be due to cross talk between ER $\alpha$ and the EGFR/MAPK pathway, which leads to a self-propogating autocrine growth-regulatory loop through ER $\alpha$ mediated development of AR [52]. Yeast and mammalian two-hybrid systems found ER and AR co-expression led to ER-AR heterodimerization, rather than ER-ER or AR-AR homodimerization, and thus a decrease in AR transactivation by $35 \%$ [43]. This fell in line with other older studies, which showed a dose-dependent decrease in AR transcriptional activity in the presence of ER co-expression and estradiol [53]. Another potential way AR down-regulates ER $\alpha$ activity is by competing for and binding to estrogen response elements (EREs) on DNA [54]. Chromatin immunoprecipitation sequencing (ChIP-seq) and gene microarray analysis of the ZR-75-1 luminal breast cancer cell line identified that increased presence of one respective steroid hormone ligand (DHT versus estradiol) over the other leads to antagonism of the other pathway, specifically at the level of transcription by binding to DNA response elements [40]. 
For example, if AR binds to EREs it leads to an anti-proliferative effect rather than the proliferative effect of ER $\alpha$ binding to ERE and vice versa for ER $\alpha$ binding to androgen response elements (AREs). In certain studies, ER and AR interplay actually leads to increased resistance to traditional endocrine targeted therapies [55,56].

ER expression serves as a primary target for therapy and one of the first treatments targeting this pathway was the anti-estrogen tamoxifen, which was FDA approved in 1998. It is a selective estrogen receptor modulator (SERM) that has differential ER agonist and antagonist activity depending on the target tissue, and acts as a competitive inhibitor of estradiol [57]. Tamoxifen-resistance can occur in HR-positive breast cancers and AR signaling has been implicated in this process, leading to some clinical insight into the relationship between ER and AR signaling pathways. Toth-Fejel and colleagues noted the androgen DHEA-S induced growth in the AR and ER-positive cell line T-47D by 43.4\%, but inhibited the AR-positive and ER-negative cell line HCC1937 by 22\% [58]. They also found that pre-treatment of the cell lines with tamoxifen in T-47D cells could increase the inhibitory activity of DHEA-S, presumably though increased activity at the level of the AR receptor.

A somewhat conflicting pre-clinical model to that of Toth-Fejel and colleagues noted in the MCF-7 cell line that overexpression of AR made ER $\alpha$-positive breast cancer cells resistant to the inhibitory effects of tamoxifen in xenograft and nude mice studies, and that treatment with anti-androgen therapy could overcome this resistance [59]. The postulated mechanism was an AR-associated increase in tamoxifen agonist activity on ER, rather than an antagonistic effect [58,59]. A more recent preclinical study found that the agonist activity of tamoxifen on ER signaling in the presence of high levels of AR leads to activation of epidermal growth factor receptor (EGFR), which could be blocked by use of the non-steroidal anti-androgen enzalutamide and/or the anti-EGFR therapy gefitinib [60]. Additionally, tamoxifen-resistant cancers in which AR is present tend to have both higher levels of AR expression and in one study, higher AR to ER nuclear expression [56].

\section{Prognostic Implications of AR in ER+ Breast Cancer}

Several larger studies and meta-analyses reviewing the prognostic implications of AR-positive breast cancer report their findings without discussion of AR in relation to co-receptor status, or male breast cancer. Given the size of these studies, and the unique look into male breast cancer, they remain important and will be discussed briefly here prior to reviewing the significance of AR in relation to ER in this section, and HER2 co-expression versus TNBC in later sections. The largest meta-analysis to date presented by Vera-Badillo and colleagues encompassed 19 studies and 7693 patients with stage I-III disease [20]. Specifically, this study looked at the odds ratios for overall survival (OS) and disease free survival (DFS) at 3 and 5 years for patients with AR expression, in which 4658 patients (60.5\%) had breast cancers that were notably AR-positive. Independent of ER expression, patients with AR-positive breast cancers were found to have statistically significant improvements in OS and DFS at both 3 year and 5 year time points, including a 13.5\% absolute improvement in 5 year OS and 20.7\% in DFS [20]. Another meta-analysis reviewing DFS and OS by Qu et al. evaluated 12 studies and 5270 patients that met their criteria. The combined hazard ratio for DFS of all included studies was 0.52 , which was statistically significant, indicating a lower risk of recurrence for patients with AR-positive breast cancers. However, although showing a trend toward improvement, the difference in OS was not statistically significant [61]. Aleskandarany et al. performed a retrospective cohort study of stage I-III patients $(n=1141)$ with tumors $\leq 5 \mathrm{~cm}$ from 1987 to 1997 [62]. High AR expression was associated with longer breast cancer specific survival (BCSS) and was an independent predictor of better outcome regardless of tumor size, grade and nodal stage. Moreover, low AR expression was associated with increased risk of distant metastasis [62]. The Nurses' Health Study (NHS) showed similar results in a prospective analysis of stage I-III patients conducted from 1976 to 2008 of postmenopausal women. AR-positive tumors were associated with small tumor size $(\leq 2 \mathrm{~cm})$, lower histologic grade, and stage. Breast cancer survival rates at 5 and 10 years were $88 \%$ and $82 \%$ for AR-negative patients, and $95 \%$ and $88 \%$ for AR-positive patients [63]. 
Regarding male breast cancer, these cases comprise only approximately $1 \%$ of all breast cancer. In a Chinese study analyzing 116 patients from 1995 to 2008, men were found to have poorer outcomes if their breast cancers were AR-positive [64]. Unlike comparable studies in female breast cancer, AR expression was not correlated with pathologic T stage, histologic grade, or HR expression. Likewise, in contrast to the studies outlined above, OS and DFS rates were significantly shorter with 5 year OS at $54 \%$ versus $72 \%$, and 5 year DFS at $39 \%$ versus $61 \%$, for AR-positive versus AR-negative cancers respectively, echoing the results of an earlier Polish study $[65,66]$. However, AR signaling in male breast cancer remains poorly understood with conflicting results, largely due to the relatively small series available. Where one study indicates a lack of correlation between AR expression and male breast cancer, another indicates decreased AR expression is correlated with earlier development of cancer $[67,68]$. Further studies are necessary to help clarify this patient population further.

In relation to ER-positive breast cancer, several studies have established that AR positivity has prognostic value. AR and ER co-expressing breast cancers generally have better outcomes in terms of time to relapse (TTR), as well as disease specific survival (DSS) as noted from a study by Castellano and colleagues [69]. The study analyzed 953 ER-positive patients from 1998 to 2003 treated with chemotherapy, hormone therapy or both, of which 859 were evaluable for AR expression and 609 were positive (70.9\%). The median TTR was 11.72 years versus 13.22 years and the DSS was 12.33 and 13.91 respectively. Regarding clinical and pathologic features, the study established a correlation with AR positivity and smaller tumor size $(<2 \mathrm{~cm})$, absence of lymph node metastases and PR expression [69].

A Swedish population-based prospective cohort study assessing patients from 2002 to 2012 also showed a statistically significant improvement in DFS (at 6 years, approximately $90 \%$ versus $78 \%$ ) in breast cancers co-expressing AR and ER [70]. Tsang et al. reviewed data from 3 Chinese institutions from the years 2002 to 2009 and showed AR and ER co-expression to be associated with lower pathologic T stage, lower tumor grade, PR positivity and better outcomes, and postulated that the favorable result could be due to the inhibitory effect of the AR signaling [34,58]. The Nurses' Health Study noted the best survival rates in AR and ER co-expressing breast cancers were in postmenopausal women with stage I-III breast cancer, with an overall $30 \%$ reduction in breast cancer mortality [63]. Jiang and colleagues also noted a significantly better DFS in the ER-positive molecular luminal (A and B) subtypes [71].

Reduced AR expression in ER-positive disease can predict for an increased risk of relapse, breast-cancer associated death and worse DFS as well [71]. A study of 215 invasive ductal carcinoma samples noted that breast cancers with higher expression (median of $75 \%$ nuclear positivity by the AR-U407 IHC assay), was associated with a 3 fold increased risk of relapse and 4.6 fold increased risk in breast cancer related death, as well as a statistically significant decrease in OS [54].

\section{AR Pathway in HER2 Amplified Breast Cancer}

The HER2 receptor in breast cancer was first noted in the late 1980s. Historically, it has been associated with poorer outcomes and is amplified in approximately $15 \%-25 \%$ of invasive breast cancers [72,73]. HER2 amplified breast cancers have lower rates of ER co-expression, ranging from $28 \%$ to $49 \%$, with typically better outcomes when ER is present [73,74]. Previous molecular studies have distinguished a group of patients with ER-negative but HER2-positive disease that did not easily fall into a pre-defined category. An important study by Farmer et al. in 2005 aimed to better define ER-negative, HER2-positive disease by tissue microarray and found an increase in AR signaling [44]. These cells in further review were notable for apocrine differentiation when exposed to high amounts of androgens in the in vitro setting, and became known as molecular apocrine with separate distinct characteristics than traditional apocrine tumors $[44,75]$. One early pre-clinical study postulated that the molecular apocrine subtype was associated with cell proliferation in the presence of androgen due to complex interactions between AR and the HER2 signal transduction pathway in the absence of interference by the ER pathway [45]. A related investigation in prostate cancer found that HER2 kinase signaling is required for full activity of AR at low androgen concentration. In particular, HER2 
signaling led to increased binding of AR to the appropriate DNA targets to promote transcription, and protected AR from ubiquitin associated degradation [76].

This interplay was further elucidated by Naderi and Hughes-Davies, who showed in the cell lines MDA-MB-453 and MDA-MB-361, and in fresh tumor samples, that there is cross-regulation of certain genes between AR and HER2. In particular, there was increased expression of steroid response genes FOXA1, XBP1 and TFF3, as well as, increased cell proliferation when either AR or HER2 were stimulated. When exposed to the anti-androgen flutamide, or HER2 inhibition there were pro-apoptotic effects, which was notably additive when given in combination [46]. Later, the same group in a study by Chia et al., further identified a positive feedback loop between the AR and extracellular signal-regulated kinase (ERK) signaling pathways, in which HER2 is a transcriptional target of AR, and leads to increased ERK activity [77]. The ERK pathway was also found to increase AR expression, which could be down-regulated both with the androgen targeting flutamide, or the ERK pathway targeting MEK inhibitor in an in vivo mouse model [77]. Similar models have been described in prostate cancer, and serve as potential therapeutic targets [78].

To further add to the complexity of AR in HER2 amplified disease, a study by Ni and colleagues looking at the AR cistrome in the MDA-MB-453 breast cancer cell line, had several interesting findings. They noted that forkhead factor binding motif FOXA1, was highly expressed in HER2 and AR-positive breast tumors, which is similar to AR-positive prostate cancers and seems to be involved in recruitment of ER and AR to their transcription regulatory elements $[28,79,80]$. AR mediated activation of HER2/HER3 signaling led to increased activity of MYC gene activity, which increased transcriptional activity of androgen-response genes in ER-negative and AR-positive molecular apocrine breast cancers [81]. In an earlier study, this same group showed DHT stimulation, likely through AR promotion of FOXA1 and wnt/B-catenin pathway led to up-regulation of HER2 and HER3 phosphorylation and activation of the phosphoinositide 3-kinse (PI3K) pathway in the MDA-MB-453 cell line.

Also identified by another group is that AR activates the Wnt/ $\beta$-catenin pathway, which leads to upregulation of HER3 and has been previously implicated in breast oncogenesis [82]. Exposure to the androgen DHT led to increased growth signaling activity of AR, HER2/HER3 and as a downstream event, and activation of PI3K/AKT pathway and these events could be blocked with the addition of the anti-androgen bicalutamide in an in vivo mouse model [28]. It should be noted that the cell line used in this study has been found to have a homozygous deletion of TP53, a homozygous PTEN missense mutation, and an oncogenic mutation in PI3K that might confound this data [83-85].

\section{Prognostic Implications of AR in HER2 Amplified Breast Cancer}

The prognostic significance of AR in HER2 amplified breast cancer seems to either show no association with survival, or indicate poorer outcomes. However, many of these studies are limited by smaller sample sizes. One analysis looking at prognostic variables in AR expressing breast cancer showed no association with BCSS or distant metastasis free interval, though this only comprised a sample of 59 patients [62]. A large prospective study assessing postmenopausal women notably had 1154 samples with AR-positive disease, but only 81 patients with HER2 amplification and noted no differences in survival [63].

Other studies, including a retrospective analysis by Park et al. analyzed 931 breast cancer tissue samples in stage I-III disease without prior therapy. Forty-nine patients with AR-positive, HER2 amplified breast cancer were categorized as molecular apocrine subtype, and survival analysis revealed a trend toward poorer OS, though this did not reach statistical significance [23]. Along these lines, Schippinger and colleagues in a study looking at 232 specimens of metastatic breast cancer noted that DFS in patients with AR expression and HER2-amplification was 9.07 months compared to 17.51 in all patients with AR expressed disease, though again not statistically significant. Moreover, the median survival after recurrence (SAR) in this population was only 10.89 months, which was similar to the 11.99 months in patients with AR-negative disease [86]. 


\section{AR Pathway in TNBC}

TNBC, as defined by lack of expression of ER and PR and a lack of HER2 amplification, comprises between $10 \%$ and $20 \%$ of all breast cancers $[48,87,88]$. Traditionally, outcomes in TNBC have been poor with a median overall survival in metastatic disease of approximately 13 months, as well as a shorter time from recurrent disease until death compared to other breast cancers $[89,90]$. Pathologic features include higher mitotic indices and an increase in BRCA1 mutations [91]. Demographically, TNBC has been associated with higher proportion of African American and Hispanic patients based on population studies and tend to occur at a higher frequency in younger patients [92-95]. Despite these common characteristics, TNBC remains a biologically variable disease and thus a common signaling pathway that could serve as a target for therapy has proven elusive [96]. Traditional cytotoxic chemotherapy remains the main approach to treatment in these patients, but significant research at the molecular level is being conducted to identify at least subsets of TNBC that might benefit from treatments focused on driver pathways such as AR signaling.

Gene expression profiling has increasingly been used to classify invasive cancer subtypes over the last 15 years. In TNBC, the majority of cases fall into a category of basal-like subtype, first described by Perou, et al. in 2000 [32]. Expanded studies on the basal-like subtype have identified that this heterogeneous group comprises approximately $16 \%$ of all breast cancers [97]. The basal-like subtype has several common and more aggressive clinical features, including higher histologic grade and mitotic indices, as well as earlier disease recurrence that lead to poorer outcomes [33,98-100]. Many of these features have clinical overlap with the broader category of TNBC. Depending on the study, the basal-like subtype is found in anywhere from $56 \%$ to $95 \%$ of cases and has sometimes been used synonymously with the term TNBC [101-104]. With improved methods in molecular biology and gene expression profiling, the heterogeneity of TNBC is becoming increasingly understood.

Lehmann et al. initially categorized TNBC into 6 separate subtypes, including basal-like 1 (BL1), basal-like 2 (BL2), immunomodulatory (IM), mesenchymal (M), mesenchymal stem-like (MSL), and luminal androgen receptor (LAR), each with distinct gene signatures predicting for driver signaling pathways that could potentially serve as therapeutic targets [48]. Specifically, the LAR subtype was found to be enriched in mRNA expression of AR signaling, as well as multiple downstream AR targets with in vitro studies showing increased sensitivity to the AR antagonist bicalutamide [48]. Lehmann and colleagues later adjusted their classification in 2016, utilizing more refined techniques, to include only 4 subtypes with the omission of the IM and MSL categories [105]. Regardless, the LAR subtype remains validated within the Lehmann lab and among other research groups, including Yu et al., and more recently Jezequel and colleagues who found the subtype to account for approximately $22 \%$ of TNBC [106,107]. Moreover, Lehmann's group later noted that all commercially available AR expressing TNBC cell lines also had PIK3CA mutations. They performed Sanger sequencing on 26 AR-positive and 26 AR-negative TNBC clinical cases, and found clonal PIK3CA mutations were significantly higher in AR-positive (40\%) versus AR-negative (4\%) tumors [108]. Further analysis of 5 LAR cell lines revealed activating PIK3CA mutations and sensitivity to PI3K inhibition suggesting interplay between these pathways as well $[48,108]$.

Even non-LAR TNBC cell lines SUM159PT, HCC1806, BT549, and MDA-MB-231 seem to have a role for AR signaling. Gene microarray and ChIP-seq analysis shows AR mediated up-regulation of the EGFR ligand amphiregulin, which promotes proliferation via the EGFR pathway. This proliferative activity appeared to be blocked with the anti-androgen enzalutamide [47].

\section{Prognostic Implications of AR in TNBC Breast Cancer}

AR positivity has been associated with more favorable prognoses in TNBC. There are several studies that show AR is associated with lower Ki-67 proliferative marker, lower mitotic score, lower histologic grade and lower clinical stage [23,27,63,109-112]. Interestingly, TNBC has been associated with the poor prognostic TP53 mutation in up to $80 \%$ of patients, but at least one study has shown that patients with AR-positive TNBC have a lower rate of TP53 mutations as 
well $[109,113]$. This improvement in histological and genetic features seems to translate to clinical benefit and AR-positive TNBC have both improved DFS and OS versus AR-negative [110,114,115] One retrospective study analyzing tissue microarrays from 287 patients with operable TNBC breast cancer found a statistically significant decrease in lymph node positivity in AR-positive disease. The same study showed a significant difference between AR-positive and AR-negative disease in which 5 year DFS was $87 \%$ versus $74.2 \%$ and 5 year OS was $94.2 \%$ versus $82.3 \%$ [114]. A prospective study by Loibl and colleagues that was linked to the German GeparTrio trial noted AR expression predicted a significantly better 5 year DFS of $85.7 \%$ compared to $65.5 \%$ and 5 year OS of $95.2 \%$ compared to $76.2 \%$ [116]. Other studies have also shown that lack of AR expression is associated with an increased risk of recurrence and distant metastases, especially in patients with lymph node positive disease [111,112].

Other analyses have shown either no difference or worse outcomes for AR-positive TNBC. McGhan et al., looking at 119 patients with resectable disease, found patients with AR-positive cancers trended toward more advanced stages (stage II and III) breast cancer, with no differences in DSS or OS [21]. Mrklic in a retrospective study analyzing 83 patients with TNBC found no difference in DFS and OS in patients with AR-positive disease versus AR-negative, though only 27 cancers were AR-positive [27]. Pistelli in a similar study analyzing 81 cancers with only 15 positive for AR showed no difference in DFS and OS, and the same was the case for Park and colleagues, in which 21 of 156 TNBC samples expressed AR and no survival differences were noted $[117,118]$. Another study with 97 AR-positive TNBC cases failed to find a difference in relapse free survival (RFS) or OS compared to AR-negative disease [119]. The large prospective NHS study previously referenced was also evaluated for the prognostic significance of AR in TNBC and found that in 78 out of 211 AR-positive TNBC there was a statistically significant $83 \%$ increase in overall mortality compared to AR-negative in a multivariate model [63]. This data conflicts with most other studies as noted above, which generally show improved to no differences in outcomes.

More recently, pathological complete response ( $\mathrm{pCR}$ ) has become a surrogate marker for outcome in patients treated with neoadjuvant therapies [120]. In terms of chemosensitivity in AR-positive TNBC, a limited number of studies have shown a lower rate of pCR. Loibl and colleagues in the GeparTrio trial showed AR-positive disease to have a pCR of $12.85 \%(n=358)$, compared to AR-negative tumors at $25.4 \%(n=315)$. In multivariate analysis, AR independently predicted pCR. Interestingly, though patients with AR-negative disease had a higher chance of achieving pCR, those with AR-positive disease had similar DFS and OS whether or not pCR was achieved [116]. Specifically, patients who achieved a pCR and had AR-negative cancers had a 5 year DFS of $77.9 \%$ and 5 year OS of $87 \%$ compared to patients who did not achieve a pCR and were AR-positive in which DFS was 77.5\% and OS 88.6\% [116]. The patients in the GeparTrio trial received a regimen of doxorubicin, cyclophosphamide and docetaxel (TAC), and if considered a non-responder, went on to receive either more TAC or vinorelbine and capecitabine prior to surgical intervention [116]. Another retrospective study by Asano and colleagues examined 177 patients with resectable early stage breast cancer treated with neoadjuvant fluorouracil, epirubicin, and cyclophosphamide (FEC100) followed by paclitaxel. Sixty-one patients were found to have TNBC, with 23 (37.7\%) of these with AR positivity. Though the numbers were quite small, the pCR rates were lower in AR-positive versus negative disease at $17.4 \%$ $(n=4)$ compared to $63.2 \%(n=24)$ [121]. Notably, the latter AR-negative pCR response was particularly robust in comparison to the Loibl study, and likely contributed to improved OS and non-recurrence free survival in AR-negative TNBC in their population [121].

Also, of interest and somewhat opposite to the above studies looking at pCR is a recent article by Jiang and colleagues in which whole exome sequencing was performed on 29 biopsy samples obtained prior to treatment of patients who were found to have either a pCR $(n=18)$ or extensive residual disease $(n=11)$ after neoadjuvant chemotherapy with adriamycin, cyclophosphamide and paclitaxel (ACT). Pathway databases were used to predict the impact of somatic mutations on certain pathways associated with cancer. Though no single mutation was found to be predictive of response 
to chemotherapy in TNBC, they did find tumors with mutations in the AR pathway and FOXA1 transcription factor networks had a significantly higher pCR $(94.1 \%$ vs. $16.6 \%)$ compared to those that did not carry such mutations [122]. The FOXA1 transcription factor is thought to be activated by AR signaling [123]. It should be noted that the study did not designate if the samples with somatic mutations in the AR or FOXA1 pathways expressed AR by IHC, which is the surrogate marker of AR pathway activity in most studies.

\section{Treatment Options in AR+ Breast Cancer}

\subsection{Bicalutamide}

As previously described, the mechanism of AR-signaling in breast cancer is quite complex and depends on the presence or absence of other signaling mechanisms in concert (Figure 2). Early pre- clinical models have shown both a proliferative effect of androgens on cell activity and an anti-proliferative effect, leading to studying the therapeutic effects of anti-androgen medications. Bicalutamide is a non-steroidal peripherally selective anti-androgen that binds AR as an antagonist [124]. One study showed that in MCF-7 cells transfected with an AR vector, androgens prevented the cells from proliferating, while the addition of the synthetic anti-androgen bicalutamide actually reversed this effect, leading to continued proliferation [41]. Another study by Toth-Fejel and colleagues further differentiated cell lines into ER and AR-positive versus ER-negative and AR-positive disease. They found ER-negative and AR-positive cells were inhibited by $22 \%$ with the addition of androgen, but that this could be reversed with pre-treatment with bicalutamide. However, bicalutamide was not studied in the cell line that was ER and AR-positive, thus it was unclear what effect it might have on cell proliferation (i.e., inhibition of cell proliferation?) [58]. De Amicis and colleagues studied the interplay between AR expression and response to the anti-estrogen tamoxifen in the ER and AR-positive MCF-7 cell line. They found in tamoxifen-resistant cells an elevated level of AR and reduced ER mRNA, essentially showing that AR overexpression was associated with tamoxifen resistance, possibly by enhancing its agonistic effects rather than antagonist. This resistance could be overcome with the addition of bicalutamide, which offers interesting therapeutic implications in tamoxifen resistance cancers in which AR is expressed [59]. Further studies assessing bicalutamide in treatment of tamoxifen resistance, or as prophylaxis to resistance, in ER and AR-positive disease are certainly warranted.

There are not many studies that have assessed the role of bicalutamide activity in HER2 amplified disease. Ni and colleagues though, did show an in vivo ability to block stimulation by androgen and induce apoptosis with the use of bicalutamide in ER-negative, AR and HER2-positive breast cancer, giving further evidence of the possible therapeutic effects of anti-androgens in certain AR-positive breast cancers [28].

Bicalutamide has been studied in TNBC. In addition to identifying the molecular LAR subtype, Lehmann and colleagues found this subtype to be quite sensitive to bicalutamide [48]. Zhu and colleagues showed in MSL TNBC cell lines MDA-MB-231 and Hs578T that androgens induce cell proliferation and inhibits apoptosis in vitro and in vivo and that bicalutamide promotes apoptosis, as well as other inhibitory effects [125]. Another study aimed at understanding the interplay between the transcription factor ZEB1, which plays a role in cancer progression by regulating the epithelial to mesenchymal transition (i.e., increased tumor migration and invasion) in breast cancer, and AR signaling in TNBC noted that by inhibiting ZEB1, AR expression was decreased and perhaps more importantly, inhibition of AR signaling with bicalutamide suppressed ZEB1 expression [126]. Mehta and colleagues analyzed the TNBC cell line MDA-MB-453, which in addition to AR positivity, also has PTEN and p53 mutations [127]. They identified 10 genes as AR targets using RT-qPCR and ChIP sequencing techniques and found that androgens promote cell proliferation and decrease apoptosis via these gene targets. They found that the addition of the anti-androgen bicalutamide could reverse this effect. Additionally, they hypothesized that the reason for poorer response to adjuvant or neoadjuvant 
chemotherapy in AR-positive TNBC was due to an AR-mediated resistance to apoptosis. The effects of paclitaxel, 5-fluorouracil and cyclophosphamide in AR-positive TNBC were studied and cells were found to have significant increases in cell survival and decreased apoptosis in the presence of androgen and that this could be reversed with the addition of bicalutamide [127]. As previously noted, patients with TNBC receiving neoadjuvant chemotherapy have been found to have lower $\mathrm{pCR}$ rates when AR-positive and this study provides rationale that perhaps targeting the AR pathway may help improve $\mathrm{pCR}$ rates [116].

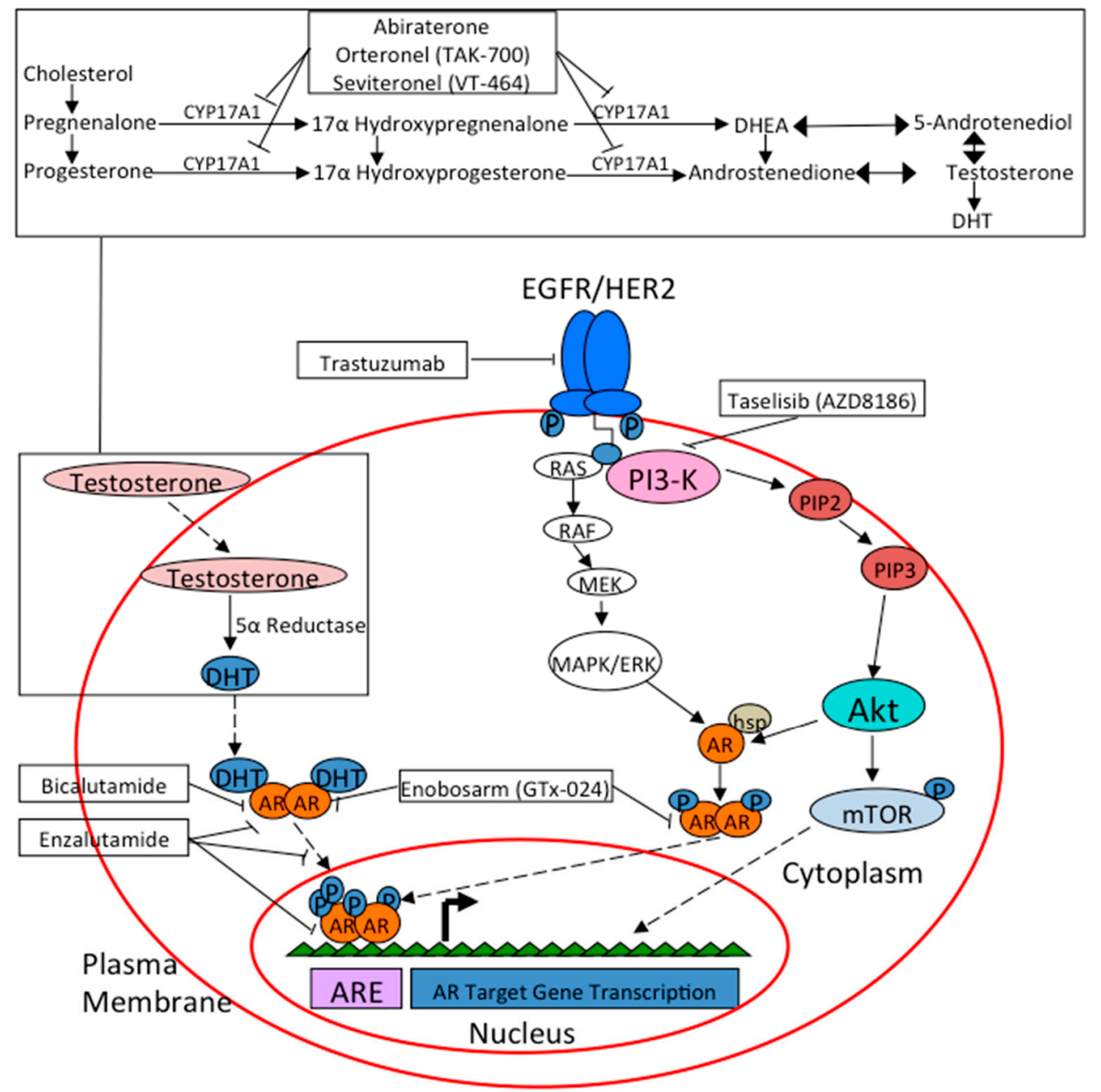

Figure 2. Drug targets in AR signaling pathway.

Evaluation of the correlation between membrane tyrosine kinase receptors and expression of AR in TNBC has shown a positive correlation with EGFR, and platelet derived growth factor beta (PDGFR $\beta$ ) [128]. The same study found increased PI3K/Akt activity in AR-positive TNBC and found that co administration of bicalutamide with agents targeting EGFR, PDGFR $\beta$, PI3K/ mammalian target of rapamycin (mTOR), and ERK pathways led to synergistic activity and provides some rationale to further evaluate combination therapy in AR-positive TNBC [128]. To further the argument that dual blockade of AR and PI3K/mTOR inhibition can lead to synergistic effects, is a study by Lehmann and colleagues. They noted a much higher rate of concurrent clonal phosphatidylinositol-4,5-bisphosphate 3-kinase, catalytic subunit alpha gene (PIK3CA) mutations (40\%) in AR-positive TNBC versus AR-negative (4\%), and also that targeting dual targeting of PI3K and AR had an additive inhibitory effect on tumor growth [108]. 
An alternative combination target may include the use of cyclin-dependent kinases 4 and 6 (CDK4 and CDK6). These kinases are activated by cyclin $\mathrm{D}$, and promote cell cycle entry by phosphorylating proteins that drive the transition from G1 to the S1 phase and when disrupted can lead to unrestricted cell proliferation in breast cancer $[129,130]$. Certain preclinical models have shown that resistance to anti-androgen therapy is linked to a F876L mutation in AR, leading to a change from antagonist activity to agonist. CDK4/ 6 inhibitors have been shown to restore activity of anti-androgen treatment by antagonizing AR F876L [131]. There is currently a phase I/II trial of palbociclib in combination with bicalutamide for the treatment of metastatic AR-positive TNBC which is accruing (NCT02605486) (Table 1) [132].

Table 1. Ongoing breast cancer clinical trials.

\begin{tabular}{|c|c|c|c|c|}
\hline Trial ID & Agent(s) & Mechanism(s) of Action & Patient Population & Study Design \\
\hline NCT02605486 & $\begin{array}{l}\text { Palbociclib \& } \\
\text { Bicalutamide }\end{array}$ & $\begin{array}{c}\text { CD4/CD6 Inhibitor \& } \\
\text { Androgen Receptor Inhibitor }\end{array}$ & $\begin{array}{l}\text { AR-positive metastatic } \\
\text { breast cancer }\end{array}$ & $\begin{array}{c}\text { Non-randomized, } \\
\text { open-label, phase I/II }\end{array}$ \\
\hline NCT02457910 & $\begin{array}{l}\text { Taselisib \& } \\
\text { Enzalutamide }\end{array}$ & $\begin{array}{l}\text { PI3K Inhibitor \& Androgen } \\
\text { Receptor Inhibitor }\end{array}$ & $\begin{array}{l}\text { AR-positive metastatic } \\
\text { TNBC }\end{array}$ & $\begin{array}{l}\text { Partially-randomized, } \\
\text { open-label phase IB/II }\end{array}$ \\
\hline NCT02091960 & $\begin{array}{l}\text { Enzalutamide \& } \\
\text { Trastuzumab }\end{array}$ & $\begin{array}{c}\text { Androgen Receptor Inhibitor } \\
\text { \& HER2 Targeted } \\
\text { Monoclonal Antibody }\end{array}$ & $\begin{array}{l}\text { AR-positive, HER2 } \\
\text { amplified metastatic or } \\
\text { locally advanced } \\
\text { breast cancer }\end{array}$ & $\begin{array}{l}\text { Non-randomized, open } \\
\text { label, phase II }\end{array}$ \\
\hline NCT02689427 & $\begin{array}{l}\text { Enzalutamide \& } \\
\quad \text { Paclitaxel }\end{array}$ & $\begin{array}{l}\text { Androgen Receptor Inhibitor } \\
\text { \& Microtubule Stabilizer }\end{array}$ & $\begin{array}{l}\text { AR-positive TNBC, stage } \\
\text { I-III breast cancer } \\
\text { (neoadjuvant therapy) }\end{array}$ & $\begin{array}{l}\text { Non-randomized, open } \\
\text { label, phase IIB }\end{array}$ \\
\hline NCT02750358 & Enzalutamide & Androgen Receptor Inhibitor & $\begin{array}{c}\text { AR-positive TNBC, stage } \\
\text { I-III breast cancer (adjuvant } \\
\text { therapy) }\end{array}$ & $\begin{array}{c}\text { Non-randomized, } \\
\text { open-label, feasibility study }\end{array}$ \\
\hline NCT00755885 & Abiraterone Acetate & CYP17 Inhibitor & $\begin{array}{c}\text { ER or AR-positive } \\
\text { postmenopausal metastatic } \\
\text { or locally advanced breast } \\
\text { cancer }\end{array}$ & $\begin{array}{c}\text { Non-randomized, } \\
\text { open-label, phase I/II }\end{array}$ \\
\hline NCT01884285 & $\begin{array}{l}\text { AZD8186+/- } \\
\text { Abiraterone Acetate } \\
\text { or AZD2014 }\end{array}$ & $\begin{array}{l}\text { PI3K Inhibitor + / - CYP17 } \\
\text { Inhibitor or mTOR Inhibitor }\end{array}$ & Advanced TNBC & $\begin{array}{l}\text { Non-randomized, } \\
\text { open-label, phase I }\end{array}$ \\
\hline NCT01990209 & Orteronel & CYP17 Inhibitor & $\begin{array}{l}\text { AR-positive metastatic } \\
\text { breast cancer }\end{array}$ & $\begin{array}{l}\text { Non-randomized, } \\
\text { open-label, phase II }\end{array}$ \\
\hline NCT02580448 & VT-464 & CYP17 Inhibitor & $\begin{array}{l}\text { Advanced breast cancer. } \\
\text { Phase I: TNBC or } \\
\text { ER-positive, HER2 negative } \\
\text { Phase II: AR-positive TNBC } \\
\text { or ER-positive, HER2 } \\
\text { negative }\end{array}$ & $\begin{array}{l}\text { Non-randomized, } \\
\text { open-label, phase I/II }\end{array}$ \\
\hline NCT02368691 & GTx-024 & $\begin{array}{l}\text { Selective Androgen Receptor } \\
\text { Modulator }\end{array}$ & $\begin{array}{l}\text { AR-positive advanced } \\
\text { TNBC }\end{array}$ & $\begin{array}{l}\text { Non-randomized, } \\
\text { open-label, phase II }\end{array}$ \\
\hline
\end{tabular}

Preclinical studies led to a phase II clinical trial evaluating bicalutamide in metastatic ER-negative and AR-positive cancers as a proof of concept study led by Gucalp and colleagues. Patients with $>10 \%$ nuclear expression of AR by IHC were included and treated with bicalutamide $150 \mathrm{mg}$ daily, with the primary endpoint being clinical benefit rate (CBR) defined as the total number of patients who showed a complete response (CR), partial response (PR) or stable disease (SD) $>6$ months. The study found the CBR to be $19 \%$ for the 26 study participants, driven by SD as there were no CRs or PRs, and a median progression free survival (PFS) of 12 weeks. Though HER2 status was not an exclusion criteria, only 1 of the 26 patients had HER2 amplified cancers and 1 of the 5 patients with SD had initial negative HER2 status that was later considered positive after undergoing a curative intent mastectomy [133]. A more recent case reported by Arce-Salinas of a patient with recurrent AR-positive metastatic TNBC, molecular apocrine subtype, had a CR with use of bicalutamide despite heavy pretreatment with palliative chemotherapy, showing that a $C R$ with anti-androgen therapy alone does seem to be possible [134]. Briefly, it should be noted that the older nonsteroidal anti-androgen flutamide, which is less potent than bicalutamide, was studied in two phase II clinical trials in 1988 in patients with metastatic breast cancer. Neither of these studies yielded promising results, though were conducted in a patient population unselected for AR, ER, PR or HER2 status $[135,136]$. 


\subsection{Enzalutamide}

Enzalutamide is a newer generation nonsteroidal anti-androgen that binds the androgen receptor with greater affinity than bicalutamide, decreases nuclear translocation, and impairs binding to androgen response elements and co-activators [137]. An interesting study by Cochrane and colleagues examined the effects of enzalutamide in AR-positive breast cancer in both ER-positive and ER-negative tumors. The study found both in vitro and in vivo that enzalutamide inhibits androgen mediated growth in both ER-positive and ER-negative cancers expressing AR. Interestingly, enzalutamide also inhibited estrogen-mediated growth in ER-positive, AR-positive cells, whereas previous preclinical studies have shown bicalutamide to increase cell proliferation in this cell population [56]. A more recent study by D'Amato and colleagues had similar results, and found AR inhibition reduced estradiol mediated proliferation in ER-positive and AR-positive disease [138]. These studies suggest that the AR signaling pathway may be a potential target in ER-positive disease as well, which has not been shown with bicalutamide. Along these lines, a number of studies have shown that when ER is expressed in breast cancer, AR positivity is associated with tamoxifen-resistance. Ciupek and colleagues suggest that in the presence of AR, tamoxifen leads to AR-mediated EGFR activation as a mechanism of resistance. This could be blocked with the use of enzalutamide and the EGFR inhibitor gefitinib and may provide a viable preventive or salvage therapy in ER-positive, AR-positive disease treated with tamoxifen [60].

In TNBC, an in vivo study by Barton and colleagues analyzed 4 TNBC cell lines (SUM159PT, HC1806, BT549, and MDA-MB-231) and noted that the anti-androgen enzalutamide was not only active in the LAR molecular subtype, but also in the M, MSL and BL2 subtypes. They noted that AR activation up-regulates the EGFR pathway, as in ER-positive disease noted above, which could be blocked by enzalutamide and makes it potentially applicable to a broader range of TNBC [47]. Combination therapy with anti-androgens and mTOR inhibition has shown some promising results and Robles and colleagues found additive anti-proliferative effect in the LAR molecular subtype in the MDA-MB-453 cell line and LAR xenograft model [139]. Given that mTOR is downstream from PI3K, this further strengthens the rationale that the PI3K is important in TNBC and a possible target with concurrent enzalutamide as well. There is currently a phase IB/II clinical trial that is in process, which is assessing the CBR at 16 weeks of the PI3K inhibitor taselisib in combination with enzalutamide in advanced TNBC (NCT02457910) [140].

Also of importance is that enzalutamide has been associated with immunogenic modulation, which may increase the susceptibility of tumor cells to immune-mediated cell death [141]. A study by Kwilas et al. showed growth inhibition with enzalutamide and abiraterone in breast cancer cells, with improved immune mediated lysis. They found this increase in immune mediated activity to be associated with increased cell surface expression of tumor necrosis factor-related apoptosis-inducing ligand (TRAIL) and reduction in expression of osteoprotegerin (OPG) [142]. Enzalutamide and the anti-androgen abiraterone acetate, which inhibits the CYP17A1 enzyme involved in androgen biosynthesis, decreased cell proliferation and enhanced immune mediated lysis in AR-positive disease. Even more interesting, both of these medications enhanced immune mediated lysis even in AR-negative disease [142]. An earlier study by Kwilas and colleagues also showed increased immune activity when a pox viral based cancer vaccine was combined with enzalutamide in in vivo mice models, and furthers the idea that this medication increases immunogenic modulation and may have importance in newer immunotherapy trials [143]. There is currently an ongoing phase II clinical trial evaluating dual therapy with enzalutamide and the monoclonal antibody trastuzumab in HER2 amplified, AR-positive metastatic breast cancer with a primary endpoint of CBR at $\geq 24$ weeks (NCT02091960) [144]. Although it would be difficult to tease out the immunogenic modulation of enzalutamide in this study, it may boost the effect of trastuzumab. Enzalutamide is also currently being assessed in several AR-positive TNBC clinical trials, either alone or in combination, which will be discussed below.

Traina and colleagues shared preliminary results of a phase II clinical trial assessing enzalutamide in AR-positive metastatic TNBC [145]. The single-arm, non-randomized phase II trial assessed patients 
with TNBC who screened for AR positivity as defined by AR expression greater than $0 \%$ by IHC. A total of 118 women were enrolled in the trial, with a majority of patients treated in the first or second line setting. The primary end point was CBR at 4 months, which was $35 \%$ at that time point, and $29 \%$ at 6 months. The median PFS was 14 weeks, and included 2 CRs and 5 PRs and the medication was well tolerated without any new safety concerns [145]. As a side benefit, the study also led to the development of a predictive assay termed PREDICT AR, in which they noted patients who responded to enzalutamide had a distinct gene expression profile, and had a better CBR of $36 \%$ at 24 weeks compared to $6 \%$ in patients who were PREDICT AR-negative $[145,146]$.

As previously discussed, patients with AR-positive TNBC have a relatively low pCR rate of $12.85 \%$ [116]. Aimed at this group is a phase IIB clinical trial in the neoadjuvant setting looking at the use of enzalutamide with weekly paclitaxel with a primary endpoint of pCR that is meant to hopefully improve the response rate (NCT02689427) [147]. There is also a feasibility study accruing that is looking at the use of 1 year of adjuvant enzalutamide for the treatment of patients with early stage, AR-positive TNBC (NCT02750358) [148].

\subsection{Abiraterone}

Abiraterone acetate is a selective, irreversible and potent inhibitor of $17 \alpha$-hydroxylase and 17,20-lyase (CYP17) enzymatic activity and is commonly used in castration-resistant prostate cancer (CRPC) [149]. It has also been studied in ER-positive metastatic breast cancer with at least part of the rationale being that CYP17 inhibition decrease the synthesis of both androgens and estrogens and may be more effective than an AI alone. A phase II, randomized open-label clinical trial assessing 297 patients with metastatic ER-positive breast cancer looked to clarify the role of abiraterone, though AR positivity was not a stratification factor. Eligibility required sensitivity to an aromatase inhibitor (AI) prior to disease progression and AR positivity was reportedly balanced between treatment arms, including abiraterone plus prednisone, versus abiraterone with exemestane versus exemestane alone with primary end point of PFS. Abiraterone either in combination with prednisone or with exemestane did not improve PFS, compared to exemestane [150,151]. Another phase II clinical trial assessed the safety and efficacy of abiraterone plus prednisone in molecular apocrine AR-positive metastatic breast cancer with a primary endpoint of CBR at 6 months. The CBR was found to be $20 \%$, which included $1 \mathrm{CR}$ and $5 \mathrm{SD}$, although the overall response rate was only $6.7 \%$ with a median PFS 2.8 months [152]. At the time of analysis, five patients remained on treatment with clinical benefit ranging between 6.4 and 24 months. There are currently two other clinical trials assessing abiraterone in breast cancer. A phase I/II UK study evaluated abiraterone in postmenopausal women with advanced metastatic ER or AR-positive breast cancer. This study is no longer recruiting, and results are awaited (NCT0075585) [153]. A phase I, open-label, multicenter trial evaluating abiraterone in combination with the PI3K inhibitor AZD8186 in a variety of solid malignancies, including TNBC, is still recruiting patients (NCT01884285) [154].

\subsection{Newer Anti-Androgens}

A number of other novel nonsteroidal anti-androgen agents are currently under analysis. Orteronel (TAK-700) is a reversible, selective CYP17 inhibitor, similar to abiraterone with a higher specificity for 17,20 lyase inhibition and known activity in CRPC [155,156]. This agent is being studied in a phase II clinical trial in patients with AR-positive metastatic breast cancer, with 2 separate cohorts assessing ER-positive disease and TNBC (NCT01990209) [157]. Seviteronel (VT-464) is a similar newer generation CYP17 inhibitor, with a current phase I/II study accruing patients with advanced breast cancer with separate cohorts for ER-positive disease and TNBC (NCT02580448) [158]. There are more potent and novel anti-androgens in development. A recent study by Kandil and colleagues showed up to 30 to 50 fold improvement in activity with the use of pure novel AR antagonists with 7-substituted umbelliferone derivatives over enzalutamide and bicalutamide respectively [159]. These agents clearly 
require further testing, but purer compounds may be important in AR-positive TNBC in the future if current clinical trials confirm a significant signal.

\subsection{SARMs}

Somewhat contradictory to other studies presenting therapeutic options, Narayanan and colleagues demonstrated in the MDA-MB-231 cell line that nonsteroidal, tissue selective androgen receptor modulators (SARMs), rather than anti-androgens could inhibit breast cancer growth [160]. They chose the genomically stable MDA-MB-231 TNBC cell line, in which they transfected an AR plasmid, over the often used MDA-MB-453 cell line as the latter is known to express mutated AR, PTEN and p53 that could potentially confound results. Both in vitro and in vivo, they found the addition of SARMs inhibited intratumoral expression of genetic pathways that promote breast cancer development, metastasis-promoting paracrine factors (i.e., IL6, MMP13) and cell proliferation [160]. Based largely on this study, a phase II, multicenter clinical trial investigating the efficacy and safety of the SARM enobosarm (GTx-024) in advanced AR-positive TNBC is currently underway (NCT02368691) [161].

\subsection{Other Drugs}

Poly ADP-ribose polymerase (PARP) inhibitors are a group of agents aimed at the PARP1 protein that acts to repair single strand breaks in DNA. These breaks occur frequently in the cell cycle, and rely on mechanisms such as PARP1 activity to resolve the errors via the base excision repair pathway. Patients with breast cancer susceptibility gene 1 (BRCA1) and 2 (BRCA2), as well as partner and localizer of BRCA2 (PALB2) mutations are susceptible to DNA double strand breaks, as these genes normally function to correct such breaks. In patients with these underlying mutations, the addition of a PARP inhibitor leads to cell death due to dysfunction of both repair pathways [162]. In regards to AR signaling and PARP inhibition, there is minimal data. However, Park and colleagues identified that BRCA1 increased ligand-dependent AR transactivation, as well as synergistically combined with co-activators of the AR pathway, leading to increased efficacy. They postulated that lack of the BRCA1 gene would reduce AR-dependent signaling [163]. Shin et al. found non-mutated BRCA2 synergizes with the co-activator p160 to enhance AR-mediated transcription, similar to BRCA1, and was associated with an anti-proliferative effect [164]. A small study evaluated 41 patients with BRCA1 mutations and 14 with BRCA2 mutations and analyzed AR status by IHC and found only $12 \%$ of BRCA1, and $50 \%$ of BRCA2 mutated tumors expressed AR [165]. Another study found AR positivity in 13 of $43(30 \%)$ BRCA1 and 14 of 18 (78\%) of BRCA2 mutated tumors [166]. At present, there have been no preclinical or clinical studies looking at PARP inhibition specifically in AR-positive disease. Although PARP inhibition has become an important tool in breast cancer treatment, especially in BRCA1, BRCA2 or PALB2 mutated cells, its activity needs to be better defined in relation to the AR pathway in preclinical models before we can identify if there is significant rationale for their use in AR-positive disease.

Bromodomain and extraterminal (BET) signaling has emerged recently as an important pathway in AR signaling. These proteins, which are expressed by the majority of cancer cells, are involved in epigenetic activity and chromatin "reading" and include BRD2, BRD3, BRD4 and BRDT [167]. BRD4 has a significant role in RNA polymerase II transcription by helping to recruit the positive transcription elongation factor P-TEFb $[168,169]$. Previous studies established the anti-cancer activity of BET inhibitors that target BRD4, which was further evaluated in CRPC by Asangani and colleagues [167]. They found BET inhibition with the small molecule JQ1 to induce G0-G1 cell cycle arrest, apoptosis and transcriptional down-regulation of anti-apoptotic BCL-xl in AR-positive cells. Moreover, they noted a direct AR-BRD4 interaction, which was inhibited by JQ1 leading to a more robust anti-proliferative effect than enzalutamide [167].

BET signaling has been studied in breast cancer as well. The ER-positive MCF-7 breast cancer cell was noted to have increased T-bet activity associated with insulin exposure, which also was associated with tamoxifen-resistance [170]. Feng and colleagues furthered this understanding by 
noting that ER signaling was positively associated with WHSC1, a histone methyltransferase recruited to the ER $\alpha$ gene by BET proteins. They found this pathway could be blocked with BET inhibition with JQ1 and overcome tamoxifen-resistance in cell culture and xenograft models [171]. Further, Sengupta et al. noted JQ1 suppression of estrogen-induced growth and transcription in MCF7 and T47D cell lines [172]. BET signaling has been studied in HER2 amplified breast cancer, using the cell lines HCC1954 and MD-MBA-361 in which it was shown that BET inhibition could overcome lapatinib resistance associated with kinome reprogramming [173]. Other studies have found that resistance to PI3K inhibitors and mTOR inhibitors is associated with feedback activation of tyrosine kinase receptors in metastatic breast cancer and can be overcome with dual use of PI3K and BET inhibition or mTOR and BET inhibition [174,175]. Borbely and colleagues noted activity of combination therapy with a histone deacetylase (HDAC) inhibitor and BET inhibitor JQ1 by increasing activity of ubiquitin-specific protease 17 (USP17), which down-regulated the Ras/MAPK pathway and thus reduced cell proliferation in 2 separate TNBC (MDA-MB-231 and BT549) and 2 ER-positive (MCF7 and T47D) cell lines [176]. Synergy with the chemotherapeutic agents docetaxel, vinorelbine, cisplatin and carboplatin has been shown with JQ1 in preclinical evaluation of several breast cancer cell lines [177]. An association with hypoxia responsive genes and angiogenesis has been noted, which can be down-regulated with BET inhibition in cell culture and xenograft models [178]. Finally, Sahini and colleagues noted that BET inhibition results in growth suppression of TNBC independent of their intrinsic molecular subtype [179]. BET signaling certainly is an exciting area in breast cancer. However, a limitation to all the above mentioned studies regarding BET and breast cancer is that none of them further clarify the role of AR signaling in the effects that are being described. Given the findings in prostate cancer showing clear activity with AR signaling and the BET pathway, it is important to clarify the role of AR and BET signaling in breast cancer in order to identify its role as a therapeutic target. Currently, there are three early phase clinical trials assessing BET inhibitors in TNBC along with other malignancies [180-182].

\section{Discussion}

Our study aimed to describe advances in understanding of the complex AR signaling pathways in relation to co-receptor signaling, as well as prognostic and therapeutic implications. However, there are some inherent limitations to the data presented. In particular, several of the above-mentioned pre-clinical studies utilize commercially available breast cancer cell lines. Though there are advantages to the use of these classic cell line models, over time multiple cycles of cell cultures can select for certain subclones that can create variability in genetic and phenotypic expression across labs [183]. For example, in one study the cell line MDA-MB-453 notably had a homozygous deletion in TP53, a homozygous PTEN missense mutation and a PI3K mutation and it is unclear if these are preserved changes in the cell line or unique to the specific version from that particular lab [127]. Several studies do utilize cells fresh tumor samples to help corroborate their findings, but many do not and thus reproducibility of the findings is a question.

Additionally, most in vitro studies do not distinguish whether the cell line, or cells from fresh biopsy material are early stage or metastatic in origin. Independent review of commercially available cell lines reveals that most are metastatic in origin, and often from malignant pleural fluid, which some might argue indicates particularly aggressive biology that does not reflect the general population [183]. Lobular carcinoma represents approximately $10 \%$ of all invasive breast cancer, and none of the above studies looking at AR signaling studied these tumors, raising concerns of the generalizability of findings in these patients. In terms of co-receptor expression, $E R \alpha$ is known to be proliferative in breast cancer but $E R \beta$ is less understood, especially in relation to AR. It is possible that $E R \beta$, as another steroid receptor, might have importance given the competitive activity between AR and ER as steroid hormones. There is also controversy over what constitutes IHC positivity of AR expression, with cut off values of $\geq 1 \%, \geq 5 \%$ or $\geq 10 \%$ depending on the study. This lack of consensus guidelines makes it difficult to interpret prognostic value of AR expression in comparison between studies. Lastly, several 
of the larger studies and meta-analyses do not distinguish differences in prognostic value of $A R$ in relation to co-receptor expression of ER, HER2 or in TNBC. These are somewhat offset by the multiple studies reviewed that do distinguish between these different subtypes of breast cancer.

AR remains an area of study that is rapidly evolving. The current study is a comprehensive review of the available data regarding the pathophysiology of AR-positive breast cancer, and makes important efforts to discuss the nuanced differences between AR-positive breast cancers in relation to co-receptor status. Also, prognostic implications of AR are discussed in the same manner, noting clear differences in ER-positive, HER2 amplified and TNBC. Therapeutic targets along the AR pathway are discussed with emphasis on novel agents and combination therapy with promising results. As our understanding of the complexities of AR signaling in regards to tumorigenesis becomes more refined, we will better be able to use AR expression as a prognostic marker and therapeutic target.

\section{Conclusions}

The identification of the AR signaling pathway in breast cancer has led to an interesting and growing field, especially in regards to basic and translational research. Not only have we identified important prognostic associations with ER-positive, HER2 amplified and TNBC, but also potential therapeutic targets either with monotherapy or in unique combinations. Clearly, there is still significant room to expand the field and grow our understanding of these complex pathways, but early work is encouraging regarding the ability to use targeted therapies in new and exciting ways and we look forward to future of the field.

Conflicts of Interest: The authors declare no conflict of interest.

\section{References}

1. Birrell, S.N.; Bentel, J.M.; Hickey, T.E.; Ricciardelli, C.; Weger, M.A.; Horsfall, D.J.; Tilley, W.D. Androgens induce divergent proliferative responses in human breast cancer cell lines. J. Steroid Biochem. Mol. Biol. 1995, 52, 459-467. [CrossRef]

2. Zhu, X.; Li, H.; Liu, J.P.; Funder, J.W. Androgen stimulates mitogen-activated protein kinase in human breast cancer cells. Mol. Cell. Endocrinol. 1999, 152, 199-206. [CrossRef]

3. Quigley, C.A.; De Bellis, A.; Marschke, K.B.; el-Awady, M.K.; Wilson, E.M.; French, F.S. Androgen receptor defects: Historical, clinical, and molecular perspectives. Endocr. Rev. 1995, 16, 271-321. [CrossRef] [PubMed]

4. Foradori, C.D.; Weiser, M.J.; Handa, R.J. Non-genomic actions of androgens. Front. Neuroendocrinol. 2008, 29, 169-181. [CrossRef] [PubMed]

5. Burger, H.G. Androgen production in women. Fertil. Steril. 2002, 77 (Suppl. S4), S3-S5. [CrossRef]

6. Davison, S.L.; Davis, S.R. Androgens in women. J. Steroid Biochem. Mol. Biol. 2003, 85, 363-366. [CrossRef]

7. Walters, K.A. Role of androgens in normal and pathological ovarian function. Reproduction 2015, 149, R193-R218. [CrossRef] [PubMed]

8. Labrie, F.; Luu-The, V.; Labrie, C.; Belanger, A.; Simard, J.; Lin, S.X.; Pelletier, G. Endocrine and intracrine sources of androgens in women: Inhibition of breast cancer and other roles of androgens and their precursor dehydroepiandrosterone. Endocr. Rev. 2003, 24, 152-182. [CrossRef] [PubMed]

9. Birrell, S.N.; Butler, L.M.; Harris, J.M.; Buchanan, G.; Tilley, W.D. Disruption of androgen receptor signaling by synthetic progestins may increase risk of developing breast cancer. FASEB J. 2007, 21, 2285-2293. [CrossRef] [PubMed]

10. Wilson, J.D.; Griffin, J.E.; Leshin, M.; George, F.W. Role of gonadal hormones in development of the sexual phenotypes. Hum. Genet. 1981, 58, 78-84. [CrossRef] [PubMed]

11. Shaaban, A.M.; O'Neill, P.A.; Davies, M.P.; Sibson, R.; West, C.R.; Smith, P.H.; Foster, C.S. Declining estrogen receptor-beta expression defines malignant progression of human breast neoplasia. Am. J. Surg. Pathol. 2003, 27, 1502-1512. [CrossRef] [PubMed] 
12. Skliris, G.P.; Munot, K.; Bell, S.M.; Carder, P.J.; Lane, S.; Horgan, K.; Lansdown, M.R.; Parkes, A.T.; Hanby, A.M.; Markham, A.F.; et al. Reduced expression of oestrogen receptor beta in invasive breast cancer and its re-expression using DNA methyl transferase inhibitors in a cell line model. J. Pathol. 2003, 201, 213-220. [CrossRef] [PubMed]

13. Roger, P.; Sahla, M.E.; Makela, S.; Gustafsson, J.A.; Baldet, P.; Rochefort, H. Decreased expression of estrogen receptor beta protein in proliferative preinvasive mammary tumors. Cancer Res. 2001, 61, 2537-2541. [PubMed]

14. Marotti, J.D.; Collins, L.C.; Hu, R.; Tamimi, R.M. Estrogen receptor-beta expression in invasive breast cancer in relation to molecular phenotype: results from the Nurses' Health Study. Mod. Pathol. 2010, 23, 197-204. [CrossRef] [PubMed]

15. Collins, L.C.; Cole, K.S.; Marotti, J.D.; Hu, R.; Schnitt, S.J.; Tamimi, R.M. Androgen receptor expression in breast cancer in relation to molecular phenotype: Results from the Nurses' Health Study. Mod. Pathol. 2011, 24, 924-931. [CrossRef] [PubMed]

16. Niemeier, L.A.; Dabbs, D.J.; Beriwal, S.; Striebel, J.M.; Bhargava, R. Androgen receptor in breast cancer: Expression in estrogen receptor-positive tumors and in estrogen receptor-negative tumors with apocrine differentiation. Mod. Pathol. 2010, 23, 205-212. [CrossRef] [PubMed]

17. Guedj, M.; Marisa, L.; de Reynies, A.; Orsetti, B.; Schiappa, R.; Bibeau, F.; MacGrogan, G.; Lerebours, F.; Finetti, P.; Longy, M.; et al. A refined molecular taxonomy of breast cancer. Oncogene 2012, 31, 1196-1206. [CrossRef] [PubMed]

18. Kuenen-Boumeester, V.; Van der Kwast, T.H.; Claassen, C.C.; Look, M.P.; Liem, G.S.; Klijn, J.G.; Henzen-Logmans, S.C. The clinical significance of androgen receptors in breast cancer and their relation to histological and cell biological parameters. Eur. J. Cancer 1996, 32, 1560-1565. [CrossRef]

19. Moinfar, F.; Okcu, M.; Tsybrovskyy, O.; Regitnig, P.; Lax, S.F.; Weybora, W.; Ratschek, M.; Tavassoli, F.A.; Denk, H. Androgen receptors frequently are expressed in breast carcinomas: Potential relevance to new therapeutic strategies. Cancer 2003, 98, 703-711. [CrossRef] [PubMed]

20. Vera-Badillo, F.E.; Templeton, A.J.; de Gouveia, P.; Diaz-Padilla, I.; Bedard, P.L.; Al-Mubarak, M.; Seruga, B.; Tannock, I.F.; Ocana, A.; Amir, E. Androgen receptor expression and outcomes in early breast cancer: A systematic review and meta-analysis. J. Natl. Cancer Inst. 2014. [CrossRef] [PubMed]

21. McGhan, L.J.; McCullough, A.E.; Protheroe, C.A.; Dueck, A.C.; Lee, J.J.; Nunez-Nateras, R.; Castle, E.P.; Gray, R.J.; Wasif, N.; Goetz, M.P.; et al. Androgen receptor-positive triple negative breast cancer: A unique breast cancer subtype. Ann. Surg. Oncol. 2014, 21, 361-367. [CrossRef] [PubMed]

22. Gucalp, A.; Traina, T.A. Triple-negative breast cancer: Role of the androgen receptor. Cancer J. 2010, 16, 62-65. [CrossRef] [PubMed]

23. Park, S.; Koo, J.; Park, H.S.; Kim, J.H.; Choi, S.Y.; Lee, J.H.; Park, B.W.; Lee, K.S. Expression of androgen receptors in primary breast cancer. Ann. Oncol. 2010, 21, 488-492. [CrossRef] [PubMed]

24. Chia, K.; O’Brien, M.; Brown, M.; Lim, E. Targeting the androgen receptor in breast cancer. Curr. Oncol. Rep. 2015. [CrossRef] [PubMed]

25. McNamara, K.M.; Yoda, T.; Takagi, K.; Miki, Y.; Suzuki, T.; Sasano, H. Androgen receptor in triple negative breast cancer. J. Steroid Biochem. Mol. Biol. 2013, 133, 66-76. [CrossRef] [PubMed]

26. Gasparini, P.; Fassan, M.; Cascione, L.; Guler, G.; Balci, S.; Irkkan, C.; Paisie, C.; Lovat, F.; Morrison, C.; Zhang, J.; et al. Androgen receptor status is a prognostic marker in non-basal triple negative breast cancers and determines novel therapeutic options. PLOS ONE 2014, 9, e88525. [CrossRef] [PubMed]

27. Mrklic, I.; Pogorelic, Z.; Capkun, V.; Tomic, S. Expression of androgen receptors in triple negative breast carcinomas. Acta Histochem. 2013, 115, 344-348. [CrossRef] [PubMed]

28. Ni, M.; Chen, Y.; Lim, E.; Wimberly, H.; Bailey, S.T.; Imai, Y.; Rimm, D.L.; Liu, X.S.; Brown, M. Targeting androgen receptor in estrogen receptor-negative breast cancer. Cancer Cell 2011, 20, 119-131. [CrossRef] [PubMed]

29. Wells, C.A.; El-Ayat, G.A. Non-operative breast pathology: Apocrine lesions. J. Clin. Pathol. 2007, 60, 1313-1320. [CrossRef] [PubMed]

30. Selim, A.G.; Wells, C.A. Immunohistochemical localisation of androgen receptor in apocrine metaplasia and apocrine adenosis of the breast: Relation to oestrogen and progesterone receptors. J. Clin. Pathol. 1999, 52, 838-841. [CrossRef] [PubMed] 
31. Safarpour, D.; Pakneshan, S.; Tavassoli, F.A. Androgen receptor (AR) expression in 400 breast carcinomas: Is routine AR assessment justified? Am. J. Cancer Res. 2014, 4, 353-368. [PubMed]

32. Perou, C.M.; Sorlie, T.; Eisen, M.B.; van de Rijn, M.; Jeffrey, S.S.; Rees, C.A.; Pollack, J.R.; Ross, D.T.; Johnsen, H.; Akslen, L.A.; et al. Molecular portraits of human breast tumours. Nature 2000, 406, 747-752. [CrossRef] [PubMed]

33. Sorlie, T.; Tibshirani, R.; Parker, J.; Hastie, T.; Marron, J.S.; Nobel, A.; Deng, S.; Johnsen, H.; Pesich, R.; Geisler, S.; et al. Repeated observation of breast tumor subtypes in independent gene expression data sets. Proc. Natl. Acad. Sci. USA 2003, 100, 8418-8423. [CrossRef] [PubMed]

34. Tsang, J.Y.; Ni, Y.B.; Chan, S.K.; Shao, M.M.; Law, B.K.; Tan, P.H.; Tse, G.M. Androgen receptor expression shows distinctive significance in ER positive and negative breast cancers. Ann. Surg. Oncol. 2014, 21, 2218-2228. [CrossRef] [PubMed]

35. Qi, J.P.; Yang, Y.L.; Zhu, H.; Wang, J.; Jia, Y.; Liu, N.; Song, Y.J.; Zan, L.K.; Zhang, X.; Zhou, M.; et al. Expression of the androgen receptor and its correlation with molecular subtypes in 980 chinese breast cancer patients. Breast Cancer 2012, 6, 1-8. [PubMed]

36. Cops, E.J.; Bianco-Miotto, T.; Moore, N.L.; Clarke, C.L.; Birrell, S.N.; Butler, L.M.; Tilley, W.D. Antiproliferative actions of the synthetic androgen, mibolerone, in breast cancer cells are mediated by both androgen and progesterone receptors. J. Steroid Biochem. Mol. Biol. 2008, 110, 236-243. [CrossRef] [PubMed]

37. Hackenberg, R.; Luttchens, S.; Hofmann, J.; Kunzmann, R.; Holzel, F.; Schulz, K.D. Androgen sensitivity of the new human breast cancer cell line MFM-223. Cancer Res. 1991, 51, 5722-5727. [PubMed]

38. Poulin, R.; Baker, D.; Labrie, F. Androgens inhibit basal and estrogen-induced cell proliferation in the ZR-75-1 human breast cancer cell line. Breast Cancer Res. Treat. 1988, 12, 213-225. [CrossRef] [PubMed]

39. Ando, S.; De Amicis, F.; Rago, V.; Carpino, A.; Maggiolini, M.; Panno, M.L.; Lanzino, M. Breast cancer: From estrogen to androgen receptor. Mol. Cell. Endocrinol. 2002, 193, 121-128. [CrossRef]

40. Need, E.F.; Selth, L.A.; Harris, T.J.; Birrell, S.N.; Tilley, W.D.; Buchanan, G. Research resource: Interplay between the genomic and transcriptional networks of androgen receptor and estrogen receptor alpha in luminal breast cancer cells. Mol. Endocrinol. 2012, 26, 1941-1952. [CrossRef] [PubMed]

41. Szelei, J.; Jimenez, J.; Soto, A.M.; Luizzi, M.F.; Sonnenschein, C. Androgen-induced inhibition of proliferation in human breast cancer MCF7 cells transfected with androgen receptor. Endocrinology 1997, 138, 1406-1412. [CrossRef] [PubMed]

42. Goldenberg, I.S.; Sedransk, N.; Volk, H.; Segaloff, A.; Kelley, R.M.; Haines, C.R. Combined androgen and antimetabolite therapy of advanced female breast cancer. A report of the cooperative breast cancer group. Cancer 1975, 36, 308-310. [CrossRef]

43. Panet-Raymond, V.; Gottlieb, B.; Beitel, L.K.; Pinsky, L.; Trifiro, M.A. Interactions between androgen and estrogen receptors and the effects on their transactivational properties. Mol. Cell. Endocrinol. 2000, 167, 139-150. [CrossRef]

44. Farmer, P.; Bonnefoi, H.; Becette, V.; Tubiana-Hulin, M.; Fumoleau, P.; Larsimont, D.; Macgrogan, G.; Bergh, J.; Cameron, D.; Goldstein, D.; et al. Identification of molecular apocrine breast tumours by microarray analysis. Oncogene 2005, 24, 4660-4671. [CrossRef] [PubMed]

45. Doane, A.S.; Danso, M.; Lal, P.; Donaton, M.; Zhang, L.; Hudis, C.; Gerald, W.L. An estrogen receptor-negative breast cancer subset characterized by a hormonally regulated transcriptional program and response to androgen. Oncogene 2006, 25, 3994-4008. [CrossRef] [PubMed]

46. Naderi, A.; Hughes-Davies, L. A functionally significant cross-talk between androgen receptor and ErbB2 pathways in estrogen receptor negative breast cancer. Neoplasia 2008, 10, 542-548. [CrossRef] [PubMed]

47. Barton, V.N.; D'Amato, N.C.; Gordon, M.A.; Lind, H.T.; Spoelstra, N.S.; Babbs, B.L.; Heinz, R.E.; Elias, A.; Jedlicka, P.; Jacobsen, B.M.; et al. Multiple molecular subtypes of triple-negative breast cancer critically rely on androgen receptor and respond to enzalutamide in vivo. Mol. Cancer Ther. 2015, 14, 769-778. [CrossRef] [PubMed]

48. Lehmann, B.D.; Bauer, J.A.; Chen, X.; Sanders, M.E.; Chakravarthy, A.B.; Shyr, Y.; Pietenpol, J.A. Identification of human triple-negative breast cancer subtypes and preclinical models for selection of targeted therapies. J. Clin. Investig. 2011, 121, 2750-2767. [CrossRef] [PubMed]

49. Rondon-Lagos, M.; Villegas, V.E.; Rangel, N.; Sanchez, M.C.; Zaphiropoulos, P.G. Tamoxifen Resistance: Emerging Molecular Targets. Int. J. Mol. Sci. 2016, 17, 1357. [CrossRef] [PubMed] 
50. Kandouz, M.; Lombet, A.; Perrot, J.Y.; Jacob, D.; Carvajal, S.; Kazem, A.; Rostene, W.; Therwath, A.; Gompel, A. Proapoptotic effects of antiestrogens, progestins and androgen in breast cancer cells. J. Steroid Biochem. Mol. Biol. 1999, 69, 463-471. [CrossRef]

51. Lapointe, J.; Fournier, A.; Richard, V.; Labrie, C. Androgens down-regulate bcl-2 protooncogene expression in ZR-75-1 human breast cancer cells. Endocrinology 1999, 140, 416-421. [CrossRef] [PubMed]

52. Britton, D.J.; Hutcheson, I.R.; Knowlden, J.M.; Barrow, D.; Giles, M.; McClelland, R.A.; Gee, J.M.; Nicholson, R.I. Bidirectional cross talk between ERalpha and EGFR signalling pathways regulates tamoxifen-resistant growth. Breast Cancer Res. Treat. 2006, 96, 131-146. [CrossRef] [PubMed]

53. Kumar, M.V.; Leo, M.E.; Tindall, D.J. Modulation of androgen receptor transcriptional activity by the estrogen receptor. J. Androl. 1994, 15, 534-542. [PubMed]

54. Peters, A.A.; Buchanan, G.; Ricciardelli, C.; Bianco-Miotto, T.; Centenera, M.M.; Harris, J.M.; Jindal, S.; Segara, D.; Jia, L.; Moore, N.L.; et al. Androgen receptor inhibits estrogen receptor-alpha activity and is prognostic in breast cancer. Cancer Res. 2009, 69, 6131-6140. [CrossRef] [PubMed]

55. Rechoum, Y.; Rovito, D.; Iacopetta, D.; Barone, I.; Ando, S.; Weigel, N.L.; O'Malley, B.W.; Brown, P.H.; Fuqua, S.A. AR collaborates with ERalpha in aromatase inhibitor-resistant breast cancer. Breast Cancer Res. Treat. 2014, 147, 473-485. [CrossRef] [PubMed]

56. Cochrane, D.R.; Bernales, S.; Jacobsen, B.M.; Cittelly, D.M.; Howe, E.N.; D'Amato, N.C.; Spoelstra, N.S.; Edgerton, S.M.; Jean, A.; Guerrero, J.; et al. Role of the androgen receptor in breast cancer and preclinical analysis of enzalutamide. Breast Cancer Res. 2014. [CrossRef] [PubMed]

57. Osborne, C.K. Tamoxifen in the treatment of breast cancer. N. Engl. J. Med. 1998, 339, 1609-1618. [PubMed]

58. Toth-Fejel, S.; Cheek, J.; Calhoun, K.; Muller, P.; Pommier, R.F. Estrogen and androgen receptors as comediators of breast cancer cell proliferation: Providing a new therapeutic tool. Arch. Surg. 2004, 139, 50-54. [CrossRef] [PubMed]

59. De Amicis, F.; Thirugnansampanthan, J.; Cui, Y.; Selever, J.; Beyer, A.; Parra, I.; Weigel, N.L.; Herynk, M.H.; Tsimelzon, A.; Lewis, M.T.; et al. Androgen receptor overexpression induces tamoxifen resistance in human breast cancer cells. Breast Cancer Res. Treat. 2010, 121, 1-11. [CrossRef] [PubMed]

60. Ciupek, A.; Rechoum, Y.; Gu, G.; Gelsomino, L.; Beyer, A.R.; Brusco, L.; Covington, K.R.; Tsimelzon, A.; Fuqua, S.A. Androgen receptor promotes tamoxifen agonist activity by activation of EGFR in ERalpha-positive breast cancer. Breast Cancer Res. Treat. 2015, 154, 225-237. [CrossRef] [PubMed]

61. Qu, Q.; Mao, Y.; Fei, X.C.; Shen, K.W. The impact of androgen receptor expression on breast cancer survival: A retrospective study and meta-analysis. PLoS ONE 2013, 8, e82650. [CrossRef] [PubMed]

62. Aleskandarany, M.A.; Abduljabbar, R.; Ashankyty, I.; Elmouna, A.; Jerjees, D.; Ali, S.; Buluwela, L.; Diez-Rodriguez, M.; Caldas, C.; Green, A.R.; et al. Prognostic significance of androgen receptor expression in invasive breast cancer: Transcriptomic and protein expression analysis. Breast Cancer Res. Treat. 2016, 159, 215-227. [CrossRef] [PubMed]

63. Hu, R.; Dawood, S.; Holmes, M.D.; Collins, L.C.; Schnitt, S.J.; Cole, K.; Marotti, J.D.; Hankinson, S.E.; Colditz, G.A.; Tamimi, R.M. Androgen receptor expression and breast cancer survival in postmenopausal women. Clin. Cancer Res. 2011, 17, 1867-1874. [CrossRef] [PubMed]

64. Siegel, R.L.; Miller, K.D.; Jemal, A. Cancer statistics, 2016. CA Cancer J. Clin. 2016, 66, 7-30. [CrossRef] [PubMed]

65. Wenhui, Z.; Shuo, L.; Dabei, T.; Ying, P.; Zhipeng, W.; Lei, Z.; Xiaohui, H.; Jingshu, G.; Hongtao, S.; Qingyuan, Z. Androgen receptor expression in male breast cancer predicts inferior outcome and poor response to tamoxifen treatment. Eur. J. Endocrinol. 2014, 171, 527-533. [CrossRef] [PubMed]

66. Kwiatkowska, E.; Teresiak, M.; Filas, V.; Karczewska, A.; Breborowicz, D.; Mackiewicz, A. BRCA2 mutations and androgen receptor expression as independent predictors of outcome of male breast cancer patients. Clin. Cancer Res. 2003, 9, 4452-4459. [PubMed]

67. Pich, A.; Margaria, E.; Chiusa, L.; Candelaresi, G.; Dal Canton, O. Androgen receptor expression in male breast carcinoma: Lack of clinicopathological association. Br. J. Cancer. 1999, 79, 959-964. [CrossRef] [PubMed]

68. Munoz, F.; Quevedo, C.; Martin, M.E.; Alcazar, A.; Salinas, M.; Fando, J.L. Increased activity of eukaryotic initiation factor 2B in PC12 cells in response to differentiation by nerve growth factor. J. Neurochem. 1998, 71, 1905-1911. [CrossRef] [PubMed] 
69. Castellano, I.; Allia, E.; Accortanzo, V.; Vandone, A.M.; Chiusa, L.; Arisio, R.; Durando, A.; Donadio, M.; Bussolati, G.; Coates, A.S.; et al. Androgen receptor expression is a significant prognostic factor in estrogen receptor positive breast cancers. Breast Cancer Res. Treat. 2010, 124, 607-617. [CrossRef] [PubMed]

70. Elebro, K.; Borgquist, S.; Simonsson, M.; Markkula, A.; Jirstrom, K.; Ingvar, C.; Rose, C.; Jernstrom, H. Combined Androgen and Estrogen Receptor Status in Breast Cancer: Treatment Prediction and Prognosis in a Population-Based Prospective Cohort. Clin. Cancer Res. 2015, 21, 3640-3650. [CrossRef] [PubMed]

71. Jiang, H.S.; Kuang, X.Y.; Sun, W.L.; Xu, Y.; Zheng, Y.Z.; Liu, Y.R.; Lang, G.T.; Qiao, F.; Hu, X.; Shao, Z.M. Androgen receptor expression predicts different clinical outcomes for breast cancer patients stratified by hormone receptor status. Oncotarget. 2016, 7, 41285-41293. [CrossRef] [PubMed]

72. Slamon, D.J.; Clark, G.M.; Wong, S.G.; Levin, W.J.; Ullrich, A.; McGuire, W.L. Human breast cancer: Correlation of relapse and survival with amplification of the HER-2/neu oncogene. Science 1987, 235, 177-182. [CrossRef] [PubMed]

73. Lal, P.; Tan, L.K.; Chen, B. Correlation of HER-2 status with estrogen and progesterone receptors and histologic features in 3,655 invasive breast carcinomas. Am. J. Clin. Pathol. 2005, 123, 541-546. [CrossRef] [PubMed]

74. Horiguchi, J.; Koibuchi, Y.; Iijima, K.; Yoshida, T.; Yoshida, M.; Takata, D.; Oyama, T.; Iino, Y.; Morishita, Y. Immunohistochemical double staining with estrogen receptor and HER2 on primary breast cancer. Int. J. Mol. Med. 2003, 12, 855-859. [CrossRef] [PubMed]

75. Sanga, S.; Broom, B.M.; Cristini, V.; Edgerton, M.E. Gene expression meta-analysis supports existence of molecular apocrine breast cancer with a role for androgen receptor and implies interactions with ErbB family. BMC Med. Genom. 2009. [CrossRef] [PubMed]

76. Mellinghoff, I.K.; Vivanco, I.; Kwon, A.; Tran, C.; Wongvipat, J.; Sawyers, C.L. HER2/neu kinase-dependent modulation of androgen receptor function through effects on DNA binding and stability. Cancer Cell 2004, 6, 517-527. [CrossRef] [PubMed]

77. Chia, K.M.; Liu, J.; Francis, G.D.; Naderi, A. A feedback loop between androgen receptor and ERK signaling in estrogen receptor-negative breast cancer. Neoplasia 2011, 13, 154-166. [CrossRef] [PubMed]

78. Shigemura, K.; Isotani, S.; Wang, R.; Fujisawa, M.; Gotoh, A.; Marshall, F.F.; Zhau, H.E.; Chung, L.W. Soluble factors derived from stroma activated androgen receptor phosphorylation in human prostate LNCaP cells: Roles of ERK/MAP kinase. Prostate 2009, 69, 949-955. [CrossRef] [PubMed]

79. Mirosevich, J.; Gao, N.; Gupta, A.; Shappell, S.B.; Jove, R.; Matusik, R.J. Expression and role of Foxa proteins in prostate cancer. Prostate 2006, 66, 1013-1028. [CrossRef] [PubMed]

80. Lupien, M.; Eeckhoute, J.; Meyer, C.A.; Wang, Q.; Zhang, Y.; Li, W.; Carroll, J.S.; Liu, X.S.; Brown, M. FoxA1 translates epigenetic signatures into enhancer-driven lineage-specific transcription. Cell 2008, 132, 958-970. [CrossRef] [PubMed]

81. Ni, M.; Chen, Y.; Fei, T.; Li, D.; Lim, E.; Liu, X.S.; Brown, M. Amplitude modulation of androgen signaling by c-MYC. Genes Dev. 2013, 27, 734-748. [CrossRef] [PubMed]

82. Turashvili, G.; Bouchal, J.; Burkadze, G.; Kolar, Z. Wnt signaling pathway in mammary gland development and carcinogenesis. Pathobiology 2006, 73, 213-223. [CrossRef] [PubMed]

83. Garay, J.P.; Karakas, B.; Abukhdeir, A.M.; Cosgrove, D.P.; Gustin, J.P.; Higgins, M.J.; Konishi, H.; Konishi, Y.; Lauring, J.; Mohseni, M.; et al. The growth response to androgen receptor signaling in ERalpha-negative human breast cells is dependent on p21 and mediated by MAPK activation. Breast Cancer Res. 2012. [CrossRef] [PubMed]

84. Wasielewski, M.; Elstrodt, F.; Klijn, J.G.; Berns, E.M.; Schutte, M. Thirteen new p53 gene mutants identified among 41 human breast cancer cell lines. Breast Cancer Res. Treat. 2006, 99, 97-101. [CrossRef] [PubMed]

85. She, Q.B.; Chandarlapaty, S.; Ye, Q.; Lobo, J.; Haskell, K.M.; Leander, K.R.; DeFeo-Jones, D.; Huber, H.E.; Rosen, N. Breast tumor cells with PI3K mutation or HER2 amplification are selectively addicted to Akt signaling. PLoS ONE 2008, 3, e3065. [CrossRef] [PubMed]

86. Schippinger, W.; Regitnig, P.; Dandachi, N.; Wernecke, K.D.; Bauernhofer, T.; Samonigg, H.; Moinfar, F. Evaluation of the prognostic significance of androgen receptor expression in metastatic breast cancer. Virchows Arch. 2006, 449, 24-30. [CrossRef] [PubMed]

87. Howlader, N.; Altekruse, S.F.; Li, C.I.; Chen, V.W.; Clarke, C.A.; Ries, L.A.; Cronin, K.A. US incidence of breast cancer subtypes defined by joint hormone receptor and HER2 status. J. Natl. Cancer Inst. 2014. [CrossRef] [PubMed] 
88. Rakha, E.A.; Elsheikh, S.E.; Aleskandarany, M.A.; Habashi, H.O.; Green, A.R.; Powe, D.G.; El-Sayed, M.E.; Benhasouna, A.; Brunet, J.S.; Akslen, L.A.; et al. Triple-negative breast cancer: Distinguishing between basal and nonbasal subtypes. Clin. Cancer Res. 2009, 15, 2302-2310. [CrossRef] [PubMed]

89. Kassam, F.; Enright, K.; Dent, R.; Dranitsaris, G.; Myers, J.; Flynn, C.; Fralick, M.; Kumar, R.; Clemons, M. Survival outcomes for patients with metastatic triple-negative breast cancer: Implications for clinical practice and trial design. Clin. Breast Cancer 2009, 9, 29-33. [CrossRef] [PubMed]

90. Dent, R.; Trudeau, M.; Pritchard, K.I.; Hanna, W.M.; Kahn, H.K.; Sawka, C.A.; Lickley, L.A.; Rawlinson, E.; Sun, P.; Narod, S.A. Triple-negative breast cancer: Clinical features and patterns of recurrence. Clin. Cancer Res. 2007, 13, 4429-4434. [CrossRef] [PubMed]

91. Boyle, P. Triple-negative breast cancer: Epidemiological considerations and recommendations. Ann. Oncol. 2012, 23 (Suppl. S6), vi7-vi12. [CrossRef] [PubMed]

92. Bauer, K.R.; Brown, M.; Cress, R.D.; Parise, C.A.; Caggiano, V. Descriptive analysis of estrogen receptor (ER)-negative, progesterone receptor (PR)-negative, and HER2-negative invasive breast cancer, the so-called triple-negative phenotype: A population-based study from the California cancer Registry. Cancer 2007, 109, 1721-1728. [CrossRef] [PubMed]

93. Carey, L.A.; Perou, C.M.; Livasy, C.A.; Dressler, L.G.; Cowan, D.; Conway, K.; Karaca, G.; Troester, M.A.; Tse, C.K.; Edmiston, S.; et al. Race, breast cancer subtypes, and survival in the Carolina Breast Cancer Study. JAMA 2006, 295, 2492-2502. [CrossRef] [PubMed]

94. Lara-Medina, F.; Perez-Sanchez, V.; Saavedra-Perez, D.; Blake-Cerda, M.; Arce, C.; Motola-Kuba, D.; Villarreal-Garza, C.; Gonzalez-Angulo, A.M.; Bargallo, E.; Aguilar, J.L.; et al. Triple-negative breast cancer in Hispanic patients: High prevalence, poor prognosis, and association with menopausal status, body mass index, and parity. Cancer 2011, 117, 3658-3669. [CrossRef] [PubMed]

95. Kwan, M.L.; Kushi, L.H.; Weltzien, E.; Maring, B.; Kutner, S.E.; Fulton, R.S.; Lee, M.M.; Ambrosone, C.B.; Caan, B.J. Epidemiology of breast cancer subtypes in two prospective cohort studies of breast cancer survivors. Breast Cancer Res. 2009. [CrossRef] [PubMed]

96. Metzger-Filho, O.; Tutt, A.; de Azambuja, E.; Saini, K.S.; Viale, G.; Loi, S.; Bradbury, I.; Bliss, J.M.; Azim, H.A., Jr.; Ellis, P.; et al. Dissecting the heterogeneity of triple-negative breast cancer. J. Clin. Oncol. 2012, 30, 1879-1887. [CrossRef] [PubMed]

97. Millikan, R.C.; Newman, B.; Tse, C.K.; Moorman, P.G.; Conway, K.; Dressler, L.G.; Smith, L.V.; Labbok, M.H.; Geradts, J.; Bensen, J.T.; et al. Epidemiology of basal-like breast cancer. Breast Cancer Res. Treat. 2008, 109, 123-139. [CrossRef] [PubMed]

98. Livasy, C.A.; Karaca, G.; Nanda, R.; Tretiakova, M.S.; Olopade, O.I.; Moore, D.T.; Perou, C.M. Phenotypic evaluation of the basal-like subtype of invasive breast carcinoma. Mod. Pathol. 2006, 19, 264-271. [CrossRef] [PubMed]

99. Nielsen, T.O.; Hsu, F.D.; Jensen, K.; Cheang, M.; Karaca, G.; Hu, Z.; Hernandez-Boussard, T.; Livasy, C.; Cowan, D.; Dressler, L.; et al. Immunohistochemical and clinical characterization of the basal-like subtype of invasive breast carcinoma. Clin. Cancer Res. 2004, 10, 5367-5374. [CrossRef] [PubMed]

100. Kennecke, H.; Yerushalmi, R.; Woods, R.; Cheang, M.C.; Voduc, D.; Speers, C.H.; Nielsen, T.O.; Gelmon, K. Metastatic behavior of breast cancer subtypes. J. Clin. Oncol. 2010, 28, 3271-3277. [CrossRef] [PubMed]

101. Prat, A.; Lluch, A.; Albanell, J.; Barry, W.T.; Fan, C.; Chacon, J.I.; Parker, J.S.; Calvo, L.; Plazaola, A.; Arcusa, A.; et al. Predicting response and survival in chemotherapy-treated triple-negative breast cancer. Br. J. Cancer. 2014, 111, 1532-1541. [CrossRef] [PubMed]

102. Sikov, W.M.; Berry, D.A.; Perou, C.M.; Singh, B.; Cirrincione, C.T.; Tolaney, S.M.; Kuzma, C.S.; Pluard, T.J.; Somlo, G.; Port, E.R.; et al. Impact of the addition of carboplatin and/or bevacizumab to neoadjuvant once-per-week paclitaxel followed by dose-dense doxorubicin and cyclophosphamide on pathologic complete response rates in stage II to III triple-negative breast cancer: CALGB 40603 (Alliance). J. Clin. Oncol. 2015, 33, 13-21. [PubMed]

103. Bastien, R.R.; Rodriguez-Lescure, A.; Ebbert, M.T.; Prat, A.; Munarriz, B.; Rowe, L.; Miller, P.; Ruiz-Borrego, M.; Anderson, D.; Lyons, B.; et al. PAM50 breast cancer subtyping by RT-qPCR and concordance with standard clinical molecular markers. BMC Med. Genom. 2012. [CrossRef] [PubMed] 
104. Prat, A.; Adamo, B.; Cheang, M.C.; Anders, C.K.; Carey, L.A.; Perou, C.M. Molecular characterization of basal-like and non-basal-like triple-negative breast cancer. Oncologist 2013, 18, 123-133. [CrossRef] [PubMed]

105. Lehmann, B.D.; Jovanovic, B.; Chen, X.; Estrada, M.V.; Johnson, K.N.; Shyr, Y.; Moses, H.L.; Sanders, M.E.; Pietenpol, J.A. Refinement of Triple-Negative Breast Cancer Molecular Subtypes: Implications for Neoadjuvant Chemotherapy Selection. PLoS ONE 2016, 11, e0157368. [CrossRef] [PubMed]

106. Yu, K.D.; Zhu, R.; Zhan, M.; Rodriguez, A.A.; Yang, W.; Wong, S.; Makris, A.; Lehmann, B.D.; Chen, X.; Mayer, I.; et al. Identification of prognosis-relevant subgroups in patients with chemoresistant triple-negative breast cancer. Clin. Cancer Res. 2013, 19, 2723-2733. [CrossRef] [PubMed]

107. Jezequel, P.; Loussouarn, D.; Guerin-Charbonnel, C.; Campion, L.; Vanier, A.; Gouraud, W.; Lasla, H.; Guette, C.; Valo, I.; Verriele, V.; et al. Gene-expression molecular subtyping of triple-negative breast cancer tumours: Importance of immune response. Breast Cancer Res. 2015. [CrossRef] [PubMed]

108. Lehmann, B.D.; Bauer, J.A.; Schafer, J.M.; Pendleton, C.S.; Tang, L.; Johnson, K.C.; Chen, X.; Balko, J.M.; Gomez, H.; Arteaga, C.L.; et al. PIK3CA mutations in androgen receptor-positive triple negative breast cancer confer sensitivity to the combination of PI3K and androgen receptor inhibitors. Breast Cancer Res. 2014. [CrossRef] [PubMed]

109. Ogawa, Y.; Hai, E.; Matsumoto, K.; Ikeda, K.; Tokunaga, S.; Nagahara, H.; Sakurai, K.; Inoue, T.; Nishiguchi, Y. Androgen receptor expression in breast cancer: Relationship with clinicopathological factors and biomarkers. Int. J. Clin. Oncol. 2008, 13, 431-435. [CrossRef] [PubMed]

110. Luo, X.; Shi, Y.X.; Li, Z.M.; Jiang, W.Q. Expression and clinical significance of androgen receptor in triple negative breast cancer. Chin. J. Cancer 2010, 29, 585-590. [CrossRef] [PubMed]

111. Rakha, E.A.; El-Sayed, M.E.; Green, A.R.; Lee, A.H.; Robertson, J.F.; Ellis, I.O. Prognostic markers in triple-negative breast cancer. Cancer 2007, 109, 25-32. [CrossRef] [PubMed]

112. Sutton, L.M.; Cao, D.; Sarode, V.; Molberg, K.H.; Torgbe, K.; Haley, B.; Peng, Y. Decreased androgen receptor expression is associated with distant metastases in patients with androgen receptor-expressing triple-negative breast carcinoma. Am. J. Clin. Pathol. 2012, 138, 511-516. [CrossRef] [PubMed]

113. Darb-Esfahani, S.; Denkert, C.; Stenzinger, A.; Salat, C.; Sinn, B.; Schem, C.; Endris, V.; Klare, P.; Schmitt, W.; Blohmer, J.U.; et al. Role of TP53 mutations in triple negative and HER2-positive breast cancer treated with neoadjuvant anthracycline/taxane-based chemotherapy. Oncotarget 2016. [CrossRef] [PubMed]

114. He, J.; Peng, R.; Yuan, Z.; Wang, S.; Peng, J.; Lin, G.; Jiang, X.; Qin, T. Prognostic value of androgen receptor expression in operable triple-negative breast cancer: A retrospective analysis based on a tissue microarray. Med. Oncol. 2012, 29, 406-410. [CrossRef] [PubMed]

115. Tang, D.; Xu, S.; Zhang, Q.; Zhao, W. The expression and clinical significance of the androgen receptor and E-cadherin in triple-negative breast cancer. Med. Oncol. 2012, 29, 526-533. [CrossRef] [PubMed]

116. Loibl, S.; Muller, B.M.; von Minckwitz, G.; Schwabe, M.; Roller, M.; Darb-Esfahani, S.; Ataseven, B.; du Bois, A.; Fissler-Eckhoff, A.; Gerber, B.; et al. Androgen receptor expression in primary breast cancer and its predictive and prognostic value in patients treated with neoadjuvant chemotherapy. Breast Cancer Res. Treat. 2011, 130, 477-487. [CrossRef] [PubMed]

117. Pistelli, M.; Caramanti, M.; Biscotti, T.; Santinelli, A.; Pagliacci, A.; De Lisa, M.; Ballatore, Z.; Ridolfi, F.; Maccaroni, E.; Bracci, R.; et al. Androgen receptor expression in early triple-negative breast cancer: Clinical significance and prognostic associations. Cancers 2014, 6, 1351-1362. [CrossRef] [PubMed]

118. Park, S.; Koo, J.S.; Kim, M.S.; Park, H.S.; Lee, J.S.; Lee, J.S.; Kim, S.I.; Park, B.W.; Lee, K.S. Androgen receptor expression is significantly associated with better outcomes in estrogen receptor-positive breast cancers. Ann. Oncol. 2011, 22, 1755-1762. [CrossRef] [PubMed]

119. Gonzalez-Angulo, A.M.; Stemke-Hale, K.; Palla, S.L.; Carey, M.; Agarwal, R.; Meric-Berstam, F.; Traina, T.A.; Hudis, C.; Hortobagyi, G.N.; Gerald, W.L.; et al. Androgen receptor levels and association with PIK3CA mutations and prognosis in breast cancer. Clin. Cancer Res. 2009, 15, 2472-2478. [CrossRef] [PubMed]

120. Von Minckwitz, G.; Untch, M.; Blohmer, J.U.; Costa, S.D.; Eidtmann, H.; Fasching, P.A.; Gerber, B.; Eiermann, W.; Hilfrich, J.; Huober, J.; et al. Definition and impact of pathologic complete response on prognosis after neoadjuvant chemotherapy in various intrinsic breast cancer subtypes. J. Clin. Oncol. 2012, 30, 1796-1804. [CrossRef] [PubMed]

121. Asano, Y.; Kashiwagi, S.; Onoda, N.; Kurata, K.; Morisaki, T.; Noda, S.; Takashima, T.; Ohsawa, M.; Kitagawa, S.; Hirakawa, K. Clinical verification of sensitivity to preoperative chemotherapy in cases of androgen receptor-expressing positive breast cancer. Br. J. Cancer 2016, 114, 14-20. [CrossRef] [PubMed] 
122. Jiang, T.; Shi, W.; Wali, V.B.; Pongor, L.S.; Li, C.; Lau, R.; Gyorffy, B.; Lifton, R.P.; Symmans, W.F.; Pusztai, L.; et al. Predictors of Chemosensitivity in Triple Negative Breast Cancer: An Integrated Genomic Analysis. PLoS Med. 2016, 13, e1002193. [CrossRef] [PubMed]

123. Robinson, J.L.; Macarthur, S.; Ross-Innes, C.S.; Tilley, W.D.; Neal, D.E.; Mills, I.G.; Carroll, J.S. Androgen receptor driven transcription in molecular apocrine breast cancer is mediated by FoxA1. EMBO J. 2011, 30, 3019-3027. [CrossRef] [PubMed]

124. Furr, B.J.; Valcaccia, B.; Curry, B.; Woodburn, J.R.; Chesterson, G.; Tucker, H. ICI 176,334: A novel non-steroidal, peripherally selective antiandrogen. J. Endocrinol. 1987, 113, R7-R9. [CrossRef] [PubMed]

125. Zhu, A.; Li, Y.; Song, W.; Xu, Y.; Yang, F.; Zhang, W.; Yin, Y.; Guan, X. Antiproliferative Effect of Androgen Receptor Inhibition in Mesenchymal Stem-Like Triple-Negative Breast Cancer. Cell. Physiol. Biochem. 2016, 38, 1003-1014. [CrossRef] [PubMed]

126. Graham, T.R.; Yacoub, R.; Taliaferro-Smith, L.; Osunkoya, A.O.; Odero-Marah, V.A.; Liu, T.; Kimbro, K.S.; Sharma, D.; O'Regan, R.M. Reciprocal regulation of ZEB1 and AR in triple negative breast cancer cells. Breast Cancer Res. Treat. 2010, 123, 139-147. [CrossRef] [PubMed]

127. Mehta, J.; Asthana, S.; Mandal, C.C.; Saxena, S. A molecular analysis provides novel insights into androgen receptor signalling in breast cancer. PLoS ONE 2015, 10, e0120622. [CrossRef] [PubMed]

128. Cuenca-Lopez, M.D.; Montero, J.C.; Morales, J.C.; Prat, A.; Pandiella, A.; Ocana, A. Phospho-kinase profile of triple negative breast cancer and androgen receptor signaling. BMC Cancer 2014. [CrossRef] [PubMed]

129. Asghar, U.; Witkiewicz, A.K.; Turner, N.C.; Knudsen, E.S. The history and future of targeting cyclin-dependent kinases in cancer therapy. Nat. Rev. Drug Discov. 2015, 14, 130-146. [CrossRef] [PubMed]

130. Dickson, C.; Fantl, V.; Gillett, C.; Brookes, S.; Bartek, J.; Smith, R.; Fisher, C.; Barnes, D.; Peters, G. Amplification of chromosome band 11q13 and a role for cyclin D1 in human breast cancer. Cancer Lett. 1995, 90, 43-50. [CrossRef]

131. Korpal, M.; Korn, J.M.; Gao, X.; Rakiec, D.P.; Ruddy, D.A.; Doshi, S.; Yuan, J.; Kovats, S.G.; Kim, S.; Cooke, V.G.; et al. An F876L mutation in androgen receptor confers genetic and phenotypic resistance to MDV3100 (enzalutamide). Cancer Discov. 2013, 3, 1030-1043. [CrossRef] [PubMed]

132. National Cancer Institute (NCI). Palbociclib in Combination with Bicalutamide for the Treatment of AR+ Metastatic Breast Cancer. NCT02605486. Available online: https://clinicaltrials.gov/ct2/show / NCT02605486 (accessed on 9 November 2016).

133. Gucalp, A.; Tolaney, S.; Isakoff, S.J.; Ingle, J.N.; Liu, M.C.; Carey, L.A.; Blackwell, K.; Rugo, H.; Nabell, L.; Forero, A.; et al. Phase II trial of bicalutamide in patients with androgen receptor-positive, estrogen receptor-negative metastatic Breast Cancer. Clin. Cancer Res. 2013, 19, 5505-5512. [CrossRef] [PubMed]

134. Arce-Salinas, C.; Riesco-Martinez, M.C.; Hanna, W.; Bedard, P.; Warner, E. Complete Response of Metastatic Androgen Receptor-Positive Breast Cancer to Bicalutamide: Case Report and Review of the Literature. J. Clin. Oncol. 2016, 34, e21-e24. [CrossRef] [PubMed]

135. Zhao, T.P.; He, G.F. A phase II clinical trial of flutamide in the treatment of advanced breast cancer. Tumori 1988, 74, 53-56. [PubMed]

136. Perrault, D.J.; Logan, D.M.; Stewart, D.J.; Bramwell, V.H.; Paterson, A.H.; Eisenhauer, E.A. Phase II study of flutamide in patients with metastatic breast cancer. A National Cancer Institute of Canada Clinical Trials Group study. Investig. New Drugs 1988, 6, 207-210. [CrossRef]

137. Tran, C.; Ouk, S.; Clegg, N.J.; Chen, Y.; Watson, P.A.; Arora, V.; Wongvipat, J.; Smith-Jones, P.M.; Yoo, D.; Kwon, A.; et al. Development of a second-generation antiandrogen for treatment of advanced prostate cancer. Science 2009, 324, 787-790. [CrossRef] [PubMed]

138. D'Amato, N.C.; Gordon, M.A.; Babbs, B.; Spoelstra, N.S.; Carson Butterfield, K.T.; Torkko, K.C.; Phan, V.T.; Barton, V.N.; Rogers, T.J.; Sartorius, C.A.; et al. Cooperative Dynamics of AR and ER Activity in Breast Cancer. Mol. Cancer Res. 2016, 14, 154-1067. [CrossRef] [PubMed]

139. Robles, A.J.; Cai, S.; Cichewicz, R.H.; Mooberry, S.L. Selective activity of deguelin identifies therapeutic targets for androgen receptor-positive breast cancer. Breast Cancer Res. Treat. 2016, 157, 475-488. [CrossRef] [PubMed]

140. National Cancer Institute (NCI). Taselisib and Enzalutamide in Treating Patients with Androgen Receptor Positive Triple-Negative Metastatic Breast Cancer. NCT 02457910. Available online: https:/ / clinicaltrials. gov/ct2/show/NCT02457910 (accessed on 9 November 2016). 
141. Ardiani, A.; Farsaci, B.; Rogers, C.J.; Protter, A.; Guo, Z.; King, T.H.; Apelian, D.; Hodge, J.W. Combination therapy with a second-generation androgen receptor antagonist and a metastasis vaccine improves survival in a spontaneous prostate cancer model. Clin. Cancer Res. 2013, 19, 6205-6218. [CrossRef] [PubMed]

142. Kwilas, A.R.; Ardiani, A.; Gameiro, S.R.; Richards, J.; Hall, A.B.; Hodge, J.W. Androgen deprivation therapy sensitizes triple negative breast cancer cells to immune-mediated lysis through androgen receptor independent modulation of osteoprotegerin. Oncotarget 2016, 7, 23498-23511. [CrossRef] [PubMed]

143. Kwilas, A.R.; Ardiani, A.; Dirmeier, U.; Wottawah, C.; Schlom, J.; Hodge, J.W. A poxviral-based cancer vaccine the transcription factor twist inhibits primary tumor growth and metastases in a model of metastatic breast cancer and improves survival in a spontaneous prostate cancer model. Oncotarget 2015, 6, 28194-28210. [CrossRef] [PubMed]

144. National Cancer Institute (NCI). A Study to Assess the Efficacy and Safety of Enzalutamide with Trastuzumab in Subjects with Human Epidermal Growth Factor Receptor 2 Positive (HER2+), Androgen Receptor Positive (AR+) Metastatic or Locally Advanced Breast Cancer. NCT02091960. Available online: https: / / clinicaltrials.gov/ct2/show / NCT02091960 (accessed on 9 November 2016).

145. Traina, T.A. Results from a phase 2 study of enzalutamide (Enza), an androgen receptor (AR) inhibitor, in advanced AR+ triple-negative breast cancer. In Proceedings of the ASCO Annual Meeting, Chicago, IL, USA, 29 May-2 June 2015.

146. Parker, J.S.; Peterson, A.C.; Tudor, I.C.; Hoffman, J.; Uppal, H. A novel biomarker to predict sensitivity to enzalutamide in TNBC. In Proceedings of the ASCO Annual Meeting, Chicago, IL, USA, 29 May-2 June 2015.

147. National Cancer Institute (NCI). Phase IIB Neoadjuvant Enzalutamide (ZT) Plus Taxol for Androgen Receptor (AR)-Positive Triple-Negative Breast Cancer (AR+ TNBC). NCT02689427. Available online: https: / / clinicaltrials.gov/ct2/show/NCT02689427 (accessed on 9 November 2016).

148. National Cancer Institute (NCI). Feasibility Study of Adjuvant Enzalutamide for the Treatment of Early Stage AR (+) Triple Negative Breast Cancer. NCT02750358. Available online: https://clinicaltrials.gov/ct2/ show / NCT02750358 (accessed on 9 November 2016).

149. Barrie, S.E.; Potter, G.A.; Goddard, P.M.; Haynes, B.P.; Dowsett, M.; Jarman, M. Pharmacology of novel steroidal inhibitors of cytochrome P450(17) alpha (17 alpha-hydroxylase/C17-20 lyase). J. Steroid Biochem. Mol. Biol. 1994, 50, 267-273. [CrossRef]

150. O'Shaughnessy, J.; Campone, M.; Brain, E.; Neven, P.; Hayes, D.; Bondarenko, I.; Griffin, T.W.; Martin, J.; De Porre, P.; Kheoh, T.; et al. Abiraterone acetate, exemestane or the combination in postmenopausal patients with estrogen receptor-positive metastatic breast cancer. Ann. Oncol. 2016, 27, 106-113. [CrossRef] [PubMed]

151. Li, W.; O’Shaughnessy, J.A.; Hayes, D.F.; Campone, M.; Bondarenko, I.; Zbarskaya, I.; Brain, E.; Stenina, M.; Ivanova, O.; Graas, M.P.; et al. Biomarker Associations with Efficacy of Abiraterone Acetate and Exemestane in Postmenopausal Patients with Estrogen Receptor-Positive Metastatic Breast Cancer. Clin. Cancer Res. 2016, 22, 6002-6009. [CrossRef] [PubMed]

152. Bonnefoi, H.; Grellety, T.; Tredan, O.; Saghatchian, M.; Dalenc, F.; Mailliez, A.; L'Haridon, T.; Cottu, P.; Abadie-Lacourtoisie, S.; You, B.; et al. A phase II trial of abiraterone acetate plus prednisone in patients with triple-negative androgen receptor positive locally advanced or metastatic breast cancer (UCBG 12-1). Ann. Oncol. 2016, 27, 812-818. [CrossRef] [PubMed]

153. National Cancer Institute (NCI). Abiraterone Acetate in Treating Postmenopausal Women with Advanced or Metastatic breast Cancer. NCT00755885. Available online: https://clinicaltrials.gov/ct2/show/ NCT00755885 (accessed on 9 November 2016).

154. National Cancer Institute (NCI). AZD8186 First Time in Patient Ascending Dose Study. NCT01884285. Available online: https:/ / clinicaltrials.gov/ct2/show/NCT01884285 (accessed on 9 November 2016).

155. Fizazi, K.; Jones, R.; Oudard, S.; Efstathiou, E.; Saad, F.; de Wit, R.; De Bono, J.; Cruz, F.M.; Fountzilas, G.; Ulys, A.; et al. Phase III, randomized, double-blind, multicenter trial comparing orteronel (TAK-700) plus prednisone with placebo plus prednisone in patients with metastatic castration-resistant prostate cancer that has progressed during or after docetaxel-based therapy: ELM-PC 5. J. Clin. Oncol. 2015, 33, 723-731. [PubMed]

156. Saad, F.; Fizazi, K.; Jinga, V.; Efstathiou, E.; Fong, P.C.; Hart, L.L.; Jones, R.; McDermott, R.; Wirth, M.; Suzuki, K.; et al. Orteronel plus prednisone in patients with chemotherapy-naive metastatic castration-resistant prostate cancer (ELM-PC 4): A double-blind, multicentre, phase 3, randomised, placebo-controlled trial. Lancet Oncol. 2015, 16, 338-348. [CrossRef] 
157. National Cancer Institute (NCI). Orteronel as Monotherapy in Patients with Metastatic Breast Cancer (MBC) that Expresses the Androgen Receptor (AR). NCT01990209. Available online: https://clinicaltrials.gov/ct2/ show / NCT01990209 (accessed on 9 November 2016).

158. National Cancer Institute (NCI). A Open-Label Study to Evaluate the Safety, Tolerability, Pharmacokinetics, Pharmacodynamics and Efficacy of VT-464 in Patients with Advanced Breast Cancer. NCT02580448. Available online: https:/ / clinicaltrials.gov/ct2/show/NCT02580448 (accessed on 9 November 2016).

159. Kandil, S.; Westwell, A.D.; McGuigan, C. 7-Substituted umbelliferone derivatives as androgen receptor antagonists for the potential treatment of prostate and breast cancer. Bioorg. Med. Chem. Lett. 2016, 26, 2000-2004. [CrossRef] [PubMed]

160. Narayanan, R.; Ahn, S.; Cheney, M.D.; Yepuru, M.; Miller, D.D.; Steiner, M.S.; Dalton, J.T. Selective androgen receptor modulators (SARMs) negatively regulate triple-negative breast cancer growth and epithelial:mesenchymal stem cell signaling. PLoS ONE 2014, 9, e103202. [CrossRef] [PubMed]

161. National Cancer Institute (NCI). Efficacy and Safety of GTx-024 in Patients with Androgen Receptor-Positive Triple Negative Breast Cancer (AR+ TNBC). NCT02368691. Available online: https://clinicaltrials.gov/ct2/ show / NCT02368691 (accessed on 9 November 2016).

162. Livraghi, L.; Garber, J.E. PARP inhibitors in the management of breast cancer: Current data and future prospects. BMC Med. 2015. [CrossRef] [PubMed]

163. Park, J.J.; Irvine, R.A.; Buchanan, G.; Koh, S.S.; Park, J.M.; Tilley, W.D.; Stallcup, M.R.; Press, M.F.; Coetzee, G.A. Breast cancer susceptibility gene 1 (BRCAI) is a coactivator of the androgen receptor. Cancer Res. 2000, 60, 5946-5949. [PubMed]

164. Shin, S.; Verma, I.M. BRCA2 cooperates with histone acetyltransferases in androgen receptor-mediated transcription. Proc. Natl. Acad. Sci. USA 2003, 100, 7201-7206. [CrossRef] [PubMed]

165. Berns, E.M.; Dirkzwager-Kiel, M.J.; Kuenen-Boumeester, V.; Timmermans, M.; Verhoog, L.C.; van den Ouweland, A.M.; Meijer-Heijboer, H.; Klijn, J.G.; van der Kwast, T.H. Androgen pathway dysregulation in BRCA1-mutated breast tumors. Breast Cancer Res. Treat. 2003, 79, 121-127. [CrossRef] [PubMed]

166. Pristauz, G.; Petru, E.; Stacher, E.; Geigl, J.B.; Schwarzbraun, T.; Tsybrovskyy, O.; Winter, R.; Moinfar, F. Androgen receptor expression in breast cancer patients tested for BRCA1 and BRCA2 mutations. Histopathology 2010, 57, 877-884. [CrossRef] [PubMed]

167. Asangani, I.A.; Dommeti, V.L.; Wang, X.; Malik, R.; Cieslik, M.; Yang, R.; Escara-Wilke, J.; Wilder-Romans, K.; Dhanireddy, S.; Engelke, C.; et al. Therapeutic targeting of BET bromodomain proteins in castration-resistant prostate cancer. Nature 2014, 510, 278-282. [CrossRef] [PubMed]

168. Jang, M.K.; Mochizuki, K.; Zhou, M.; Jeong, H.S.; Brady, J.N.; Ozato, K. The bromodomain protein Brd4 is a positive regulatory component of $\mathrm{P}-\mathrm{TEFb}$ and stimulates RNA polymerase II-dependent transcription. Mol. Cell 2005, 19, 523-534. [CrossRef] [PubMed]

169. Yang, Z.; Yik, J.H.; Chen, R.; He, N.; Jang, M.K.; Ozato, K.; Zhou, Q. Recruitment of P-TEFb for stimulation of transcriptional elongation by the bromodomain protein Brd4. Mol. Cell 2005, 19, 535-545. [CrossRef] [PubMed]

170. McCune, K.; Bhat-Nakshatri, P.; Thorat, M.A.; Nephew, K.P.; Badve, S.; Nakshatri, H. Prognosis of hormone-dependent breast cancers: Implications of the presence of dysfunctional transcriptional networks activated by insulin via the immune transcription factor T-bet. Cancer Res. 2010, 70, 685-696. [CrossRef] [PubMed]

171. Feng, Q.; Zhang, Z.; Shea, M.J.; Creighton, C.J.; Coarfa, C.; Hilsenbeck, S.G.; Lanz, R.; He, B.; Wang, L.; Fu, X.; et al. An epigenomic approach to therapy for tamoxifen-resistant breast cancer. Cell Res. 2014, 24, 809-819. [CrossRef] [PubMed]

172. Sengupta, S.; Biarnes, M.C.; Clarke, R.; Jordan, V.C. Inhibition of BET proteins impairs estrogen-mediated growth and transcription in breast cancers by pausing RNA polymerase advancement. Breast Cancer Res. Treat. 2015, 150, 265-278. [CrossRef] [PubMed]

173. Stuhlmiller, T.J.; Miller, S.M.; Zawistowski, J.S.; Nakamura, K.; Beltran, A.S.; Duncan, J.S.; Angus, S.P.; Collins, K.A.; Granger, D.A.; Reuther, R.A.; et al. Inhibition of Lapatinib-Induced Kinome Reprogramming in ERBB2-Positive Breast Cancer by Targeting BET Family Bromodomains. Cell Rep. 2015, 11, 390-404. [CrossRef] [PubMed] 
174. Stratikopoulos, E.E.; Dendy, M.; Szabolcs, M.; Khaykin, A.J.; Lefebvre, C.; Zhou, M.M.; Parsons, R. Kinase and BET Inhibitors Together Clamp Inhibition of PI3K Signaling and Overcome Resistance to Therapy. Cancer Cell 2015, 27, 837-851. [CrossRef] [PubMed]

175. Bihani, T.; Ezell, S.A.; Ladd, B.; Grosskurth, S.E.; Mazzola, A.M.; Pietras, M.; Reimer, C.; Zinda, M.; Fawell, S.; D'Cruz, C.M. Resistance to everolimus driven by epigenetic regulation of MYC in ER+ breast cancers. Oncotarget 2015, 6, 2407-2420. [CrossRef] [PubMed]

176. Borbely, G.; Haldosen, L.A.; Dahlman-Wright, K.; Zhao, C. Induction of USP17 by combining BET and HDAC inhibitors in breast cancer cells. Oncotarget 2015, 6, 33623-33635. [PubMed]

177. Perez-Pena, J.; Serrano-Heras, G.; Montero, J.C.; Corrales-Sanchez, V.; Pandiella, A.; Ocana, A. In Silico Analysis Guides Selection of BET Inhibitors for Triple-Negative Breast Cancer Treatment. Mol. Cancer Ther. 2016, 15, 1823-1833. [CrossRef] [PubMed]

178. Da Motta, L.L.; Ledaki, I.; Purshouse, K.; Haider, S.; De Bastiani, M.A.; Baban, D.; Morotti, M.; Steers, G.; Wigfield, S.; Bridges, E.; et al. The BET inhibitor JQ1 selectively impairs tumour response to hypoxia and downregulates CA9 and angiogenesis in triple negative breast cancer. Oncogene 2017, 36, 122-132. [CrossRef] [PubMed]

179. Sahni, J.M.; Gayle, S.S.; Bonk, K.L.; Vite, L.C.; Yori, J.L.; Webb, B.; Ramos, E.K.; Seachrist, D.D.; Landis, M.D.; Chang, J.C.; et al. Bromodomain and Extraterminal Protein Inhibition Blocks Growth of Triple-negative Breast Cancers through the Suppression of Aurora Kinases. J. Biol. Chem. 2016, 291, 23756-23768. [CrossRef] [PubMed]

180. National Cancer Institute (NCI). A Dose-Finding Study of OTX105/MK-8628, a Small Molecule Inhibitor of the Bromodomain and Extra-Terminal (BET) Proteins, in Adults with Selected Advanced Solid Tumors (MK-8628-003). NCT02259114. Available online: https://clinicaltrials.gov/ct2/show/NCT02259114 (accessed on 9 November 2016).

181. National Cancer Institute (NCI). A Dose Exploration Study with MK-8628 in Participants with Selected Advanced Solid Tumors (MK-8628-006). NCT02698176. Available online: https://clinicaltrials.gov/ct2/ show / NCT02698176 (accessed on 9 November 2016).

182. National Cancer Institute (NCI). A Study to Investigate Safety, Pharmacokinetics, Pharmacodynamics, and Clinical Activity of GSK525762 in Subjects with NUT Midline Carcinoma (NMC) and Other Cancers. NCT01587703. Available online: https://clinicaltrials.gov/ct2/show/NCT01587703 (accessed on 9 November 2016).

183. Burdall, S.E.; Hanby, A.M.; Lansdown, M.R.; Speirs, V. Breast cancer cell lines: Friend or foe? Breast Cancer Res. 2003, 5, 89-95. [CrossRef] [PubMed] 